\title{
cruzamento de tradições visuais nos espetáculos de projeções ópticas realizados em Porto Alegre entre 1861 e $1908^{1}$
}

\begin{abstract}
Alice Dubina Trusz ${ }^{2}$
RESUMO: $\bigcirc$ objetivo central deste artigo é apresentar algumas das práticas que caracterizaram a exploração comercial das imagens ópticas em Porto Alegre, particularmente das vistas fixas de lanterna mágica, exibidas em espetáculos públicos de projeções realizados entre 1861 e 1908. A identificação dos usos e associações que dinamizaram aquela experiência em dois contextos distintos, anterior e posterior à introdução do cinema na cidade(1896), permite observar as continuidades e transformações nos modos de mostrar e de ver, e suas implicações na constituição da visualidade moderna.

PALAVRAS-CHAVE: Diversões ópticas. Espetáculos de projeções. Lanterna mágica. Cinema.

ABSTRACT: The main objective of this paper is to present some of the practices that characterized the commercial exploitation of projected images in Porto Alegre, particularly that of magic lantern still images as shown in public projections between 1861 and 1908. By identifying the uses and associations that gave an impetus to this experience in two different settings - i.e. prior to and after the advent of cinema in the city (1896) - it is possible to observe how certain ways of showing and seeing have remained unchanged or evolved, as well as its implications for the constitution of modern visuality.

KEYWORDS: Optical entertainment. Projection shows. Magic lantern. Cinema.
\end{abstract}

A finalidade deste estudo é apresentar algumas das características da trajetória das vistas fixas de projeção exibidas em Porto Alegre, como atrações de espetáculos públicos entre 1861 e 1908. O período delimitado engloba duas tradições espetaculares distintas, lanternista e cinematográfica, encerrando-se com o início da sedentarização do cinema. Hegemônica até 1896, quando surgiu o cinematógrafo 3 , a tradição lanternista teve continuidade, embora decrescente, na fase de exibição itinerante do cinema (1896-1908), quando as vistas fixas
1. Versão final do trabalho apresentado no IV Simpósio Nacional de História Cultural, realizado em Goiânia em 2008, promovido pela Anpuh e Universidade Católica de Goiás, no âmbito do minissimpósio 1: História, Fotografia e Cultura Visual: reflexões sobre o estatuto das imagens, formas de produção e usos sociais no tempo, coordenado por Solange Ferraz de Lima (Museu Paulista da Universidade de São Paulo) e Charles Monteiro (Pontificia Universidade Católica do Rio Grande do Sul).

2. Doutora em História pela Universidade Federal do Rio Grande do Sul. E-mail: <alice trusz@hotmail.com>.

3. O termo "cinematógrafo", aqui empregado, designa os aparelhos de projeções cinematográficas em geral, sem referir-se especificamente ao aparelho projetor desenvolvido pelos Irmãos Lumière em 1895. A opção, além de respeitar um uso corrente no período investigado, também decorre do desinteresse e da dificuldade de identificação dos modelos originais dos projetores cinematográficos exibidos localmente entre 1896 e 1908, apresentados por seus exibidores sob no- 
mes fantasiosos, tal qual aconteceu com as lanternas mágicas.

4. Ver Alice D. Trusz (2008).

5. Como exemplos, podem ser citadas as obras de Vicente de Paula Araújo (1976 e 1981), Máximo Barro (1996), Alice Gonzaga (1996) e Adolfo Morales de los Rios F. (1946), que se restringem aos contextos carioca e paulista. Em Porto Alegre, o pesquisador Antônio Jesus Pfeil (1999) foi o único que se mostrou conhecedor do tema, mas não ultrapassou o tratamento referido. Os dados que arrolou tiveram por fonte a pesquisa de Athos Damasceno Ferreira (1902-1975), que hoje se torna o primeiro historiador das formas de entretenimento óptico anteriores ao advento do cinematógrafo na cidade na medida em que contemplou tais manifestações, entre outras, em seu livro Palco, salão e picadeiro em Porto Alegre no século XIX (1956). acabaramassociadasàquelasanimadas. Pretende-seapresentaras particularidades e os aspectos comungados pelos dois gêneros no que respeita às práticas de exibição das imagens ópticas.

A temática abordada foi descoberta e investigada a partir de uma preocupação em historicizar as origens do espetáculo cinematográfico na capital gaúcha, o que também explica as referências ao gênero e as presentes delimitações cronológicas ${ }^{4}$. Essa indagação colocou a necessidade de identificar a qualidade das ofertas de entretenimento, e das relações entre elas e seus públicos, na virada dos séculos XIX para XX. Objetivava-se evidenciar a dinâmica do setor de diversões públicas local e suas transformações, identificando sua forma de organização e funcionamento, assim como os interesses e expectativas em torno dos quais foram empreendidas as práticas culturais. $\bigcirc$ fim último era caracterizar a formação cultural dos porto-alegrenses e compreender a qualidade de suas primeiras experiências como espectadores cinematográficos.

A pesquisa acabou demonstrando que a experiência dos portoalegrenses como espectadores de espetáculos públicos de projeções de imagens não havia iniciado em 1896, mas quase cinco décadas antes, modificando o próprio significado da introdução do cinema no meio local. Uma segunda constatação, igualmente inesperada, mas já decorrente da pesquisa sobre o período seguinte (a primeira década da exibição cinematográfica) foi a de que houve uma continuidade da exibição das imagens em suporte placa de vidro para projeção, asvistasfixas, nos espetáculos realizados pelos exibidorescinematográficos itinerantes entre 1897 e 1908.

Tais evidências instigaram a elaboração deste texto, focado nas práticas espetaculares que orientaram a exploração das vistas ópticas, fixas e animadas (ou cinematográficas), nos dois contextos. Divulgando-as, pretende-se chamar a atenção para este outro âmbito da relação dos contemporâneos com as imagens técnicas e as projeções luminosas, além dos usos domésticos e amadores das lanternas mágicas (os projetores de vistas fixas), e salientar a complexidade e riqueza concernentes à temática, aos processos e aos contextos estudados do ponto de vista da visualidade.

Na historiografia local, os espetáculos de projeções de lanterna mágica, assim como as caixas de óptica, formas de entretenimento visual ainda mais antigas, contam com um desconhecimento e um consequente desinteresse. Também nas obras dos estudiosos da história do cinema e nas de cronistas e memorialistas que de alguma forma contemplaram tais manifestações no país, estas foram abordadas sob um olhar que as reduziu a formas pitorescas de distração. Percebidas como uma miscelânea de atrações e práticas curiosas, foram comumente arroladas para fins de reconstituição do contexto geral das diversões, onde foi introduzido o "revolucionário", moderno e civilizador cinematógrafo5. Tais práticas culturais não mereceram maior atenção enquanto formas culturais particulares de exploração das invenções e diversões ópticas de origem europeia no contexto brasileiro. Tampouco os estudiosos da fotografia têm-se dedicado à investigação da intensa circulação nacional de que foram objeto as imagens em suporte placa de vidro para projeção. $\bigcirc$ mesmo silêncio estende-se aos projetores e aos profissionais 
que deles lançaram mão para incrementar as diversões públicas e outros âmbitos da circulação e apropriação das imagens. No entanto, o amplo interesse pelos seus diversificados usos e efeitos acabou envolvendo muitos fotógrafos com a produção e exibição cinematográfica, e também com a produção de vistas fotográficas para projeção.

Entre as razões da ausência, pode-se citar o desconhecimento do tema, relacionado à inexistência de coleções significativas de materiais dessa tipologia nos acervos dos nossos museus ${ }^{6}$. As raras referências literárias também contribuem para a uma percepção equivocada sobre os âmbitos de atuação e os tipos de emprego das lanternas mágicas e suas vistas, restrita ao meio doméstico e/ou amador e às tradicionais placas com imagens pintadas à mão, e não, fotográficas. A dificuldade também se relaciona ao fato das projeções luminosas terem sido exibidas como atrações complementares de espetáculos de outros gêneros de diversões, ao menos para o caso de Porto Alegre. Por outro lado, essa carência também é devida à deliberada desconsideração da exibição das vistas fixas nos espetáculos de projeções cinematográficas pelos estudiosos da história do cinema, preocupados em atribuir ao mesmo um ineditismo, uma "pureza" e um caráter revolucionário que os estudos sobre as formas de entretenimento óptico anteriores ao cinema vêm problematizando.

Rompendo com este quadro, Maria Cristina M. da Silva procurou mensurar e qualificar "a presença dos aparelhos e dispositivos ópticos no Rio de Janeiro do século XIX"7, identificando os "usuários difusores" dos dispositivos e seus espaços sociais de utilização. Em sua volumosa pesquisa de doutorado, a autora procurou examinar as implicações dessas manifestações para o incremento das sociabilidades e a formação do observador moderno. Embora tenha provado a significativa circulação de que foram objeto tais dispositivos e imagens na Capital Federal durante o século XIX, não esteve entre as suas preocupações verificar mais detidamente de que natureza eram os dispositivos empregados e as imagens por eles exibidas, e que práticas envolveram o cotidiano da sua exibição e apropriação em função de tais especificidades. Igualmente, privilegiou a indistinção entre os usos públicos e privados dos dispositivos ópticos, preferindo tomar o heterogêneo conjunto sob uma perspectiva mais ampla, capaz de demonstrar a extensão e variedade da sua presença.

Investigações como a citada acima e aquela que dá origem a este texto foram estimuladas pelas pesquisas estrangeiras sobre as experiências e diversões ópticas que dinamizaram o contexto do surgimento do cinema e os séculos que o antecederam, desenvolvidas sobretudo pelos historiadores do cinema, da cultura e da arte, embora raras sejam as traduções brasileiras desses estudos $^{8}$. Tais produções vêm demonstrando o largo emprego das placas de lanterna mágica como mais um suporte apropriado à reprodução massiva de imagens, inclusive fotográficas e de temática turística e artística, num processo contemporâneo àquele da produção, circulação e apropriação de fotografias de viagem e álbuns de vistas urbanas.

Esses aparelhos, imagens e práticas tiveram participação decisiva na construção de uma cultura visual socialmente generalizada, participando ativa e
6. Em Porto Alegre, foram identificadas peças do gênero apenas no Museu de Comunicação Social Hipólito José da Costa. Trata-se de três placas de vidro para projeção, de uso infantil e produção industrializada, mas quebradas e sem identificação, assim como uma pequena lanterna de projeção bifuncional, apropriada à projeção de placas de vidro e filmes $35 \mathrm{~mm}$, com lâmpada de querosene e provável uso infantil. Em São Paulo, foram localizadas, na Cinemateca Brasileira, placas de vidro para projeção, fotográficas e ilustradas, mas igualmente sem identificação e vitimadas por um incêndio. O Museu Paulista da Universidade de São Paulo possui placas fotográficas para projeção sobre a temática da aviação e uma belíssima lanterna mágica que pertenceu ao fotógrafo Augusto Militão, mas que, pelas suas dimensões e fonte luminosa, deve ter sido objeto de uso doméstico.

7. Ver Maria Cristina M. da Silva (2006)

8. A publicação do livro organizado por Leo Charney e Vanessa R. Schwartz, O cinema e a invenção da vida moderna (2001) e, principalmente, de $A$ grande arte da luz e da sombra. Arqueologia do cinema (2003), de Laurent Mannoni, foram as mais significativas contribuições nesse sentido. 
9. As fotografias estereoscópicas foram introduzidas em Porto Alegre em novembro de 1855 por Luiz Terragno. Na ocasião, o fotógrafo, reconhecido como o primeiro a estabelecer atelier fixo na cidade, publicou um anúncio na imprensa local, divulgan do ter recebido um aparelho capaz de tirar "retratos stereoscópicos ao electrotypo" com "um relevo tal que iguala à natureza". Cf. Anúncio em $O$ Mercantil, Porto Alegre, ano 6, n. 269, 29 nov. 1855 , p. 4

10. A apropriação destas imagens foi empreendida também no ambiente privado e doméstico, com suas características peculiares próprias, paralelamente ao estabelecimento de um comércio especializado em artigos ópticos para fins científicos e de entretenimento, sobretudo nas últimas décadas do século XIX. Estas outras facetas do processo, porém, não são objeto deste estudo, restrito às manifestações públicas $\mathrm{e}$ espetaculares das diversões ópticas.

11. Ver P. Levie (2006). fundamentalmente da formação dos regimes visuais que constituíram, também em Porto Alegre, terreno fértil para a vulgarização da própria fotografia e do cinema. Eles estiveram entre as opções locais de entretenimento da época, juntamente com os espetáculos teatrais, circenses, musicais e tauromáquicos, e foram de fundamental importância na intensificação do contato dos contemporâneos com as representações visuais do mundo e, mais especificamente, na sua formação como espectadores de espetáculos de projeções. Nesse sentido, é apropriado pensar-se o próprio surgimento do cinema como um momento de um processo maior e em desenvolvimento, relacionado às novas perspectivas visuais de apropriação e expressão da realidade, do qual este foi simultaneamente expressão e motor.

\section{Manifestações oitocentistas das diversões ópticas}

Na segunda metade do século XIX, além das fotografias comuns e estereoscópicas?, foram conhecidas e apreciadas na capital gaúcha as vistas de perspectiva e as placas de lanterna mágica, nos âmbitos tanto domésticos quanto públicos em que foram apresentadas por exibidores itinerantes ${ }^{10}$. As vistas de perspectiva eram observadas pelas oculares de dispositivos denominados caixas de óptica; já as placas de vidro eram projetadas em paredes ou telas por um aparelho distinto, denominado lanterna mágica o primeiro e mais popular projetor da história até a invenção do cinematógrafo. Os dois aparelhos ópticos, embora distintos, foram muito confundidos na iconografia dos séculos XVII ao XIX, para o que contribuíram seus próprios exibidores, que costumavam levar ambos às costas, sobrepostos, alternando a sua exibição. Durante o dia, exibiam as caixas com suas vistas de perspectiva e, à noite, faziam as projeções ${ }^{11}$. Acrescente-se que a imprensa brasileira novecentista foi um espaço de farta observação e disseminação desta confusão, originada na diversidade de denominações que os aparelhos receberam de seus próprios exibidores, mas que devia estender-se ao consumo cotidiano das diversões ópticas.

A caixa de óptica era um aparelho de observação individual de vistas a partir do exterior. Surgida no século XVI, na ltália, e relacionada à descoberta da perspectiva e das propriedades dos espelhos e lentes, espalhou-se rapidamente por outros países europeus nos séculos seguintes. $\bigcirc$ interesse crescente pelo dispositivo levou ao desenvolvimento de modelos tanto de grandes dimensões quanto portáteis. Os primeiros destinavam-se a profissionais itinerantes ou fixos, que se especializaram na sua exibição em feiras, mercados, praças e gabinetes. Tais dispositivos podiam dispor de até dez visores em sua face frontal, permitindo a visão simultânea das vistas por tantas pessoas quantas fossem as oculares disponíveis, conforme pode ser observado na Figura 1 Os segundos apropriavamse ao consumo doméstico e privado, âmbito em que os dispositivos ópticos e suas respectivas imagens tornariam-se cada vez mais presentes. Esses exemplares de uso familiar dispunham de uma ou duas oculares e eram frequentemente mais sofisticados e ornamentados. 


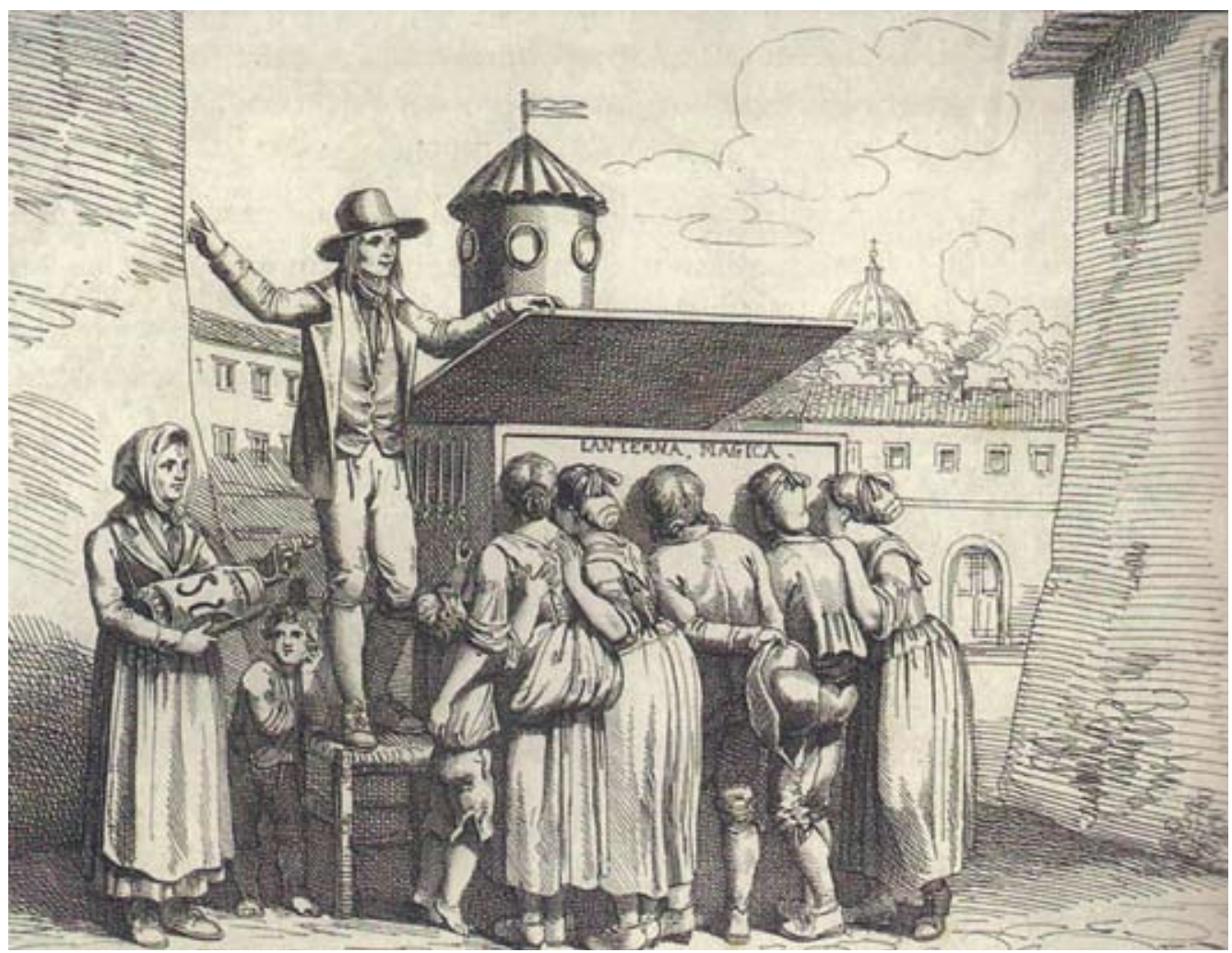

FIGURA 1 - Caixa de óptica. Gravura, Itália, 1815. Observe-se a equivocada inscrição "Lanterna Mágica" no alto da caixa, embora a imagem represente um modelo comum de caixa de óptica com múltiplas oculares, que costumava ser exibida nas ruas por demonstradores itinerantes. Neste caso, o exibidor ergue a tampa frontal da caixa, de maneira que a vista receba luz natural e possa ser observada com efeito diurno. Enquanto isso, sua assistente atrai os curiosos tocando um instrumento musical. Acervo da Cinemateca Francesa, Paris. Reproduzida em: PISANO, G. e POZNER, V. (Org.) Le muet a la parole. Cinéma et performances à l'aube du XX siècle. Paris: AFRHC, 2005, p. 104. Cortesia Cinemateca Francesa.

Através de um visor munido de uma lente biconvexa, o observador via uma imagem disposta no interior e no fundo da caixa. As vistas ópticas ou de perspectiva eram um tipo especial de gravura impressa pintada, representando logradouros públicos, edificações e monumentos, desenhados em perspectiva. Ou seja, havia uma opção por determinados temas, e pela forma de representálos e enquadrá-los, que respondia ao intuito de proporcionar ao observador uma impressão de profundidade e relevo. Sob o aspecto da temática representada, as vistas mais comuns foram as "topográficas", isto é, que proporcionavam visões panorâmicas de cidades, fossem conhecidas, desconhecidas ou exóticas, ou mesmo as já destruídas e míticas ${ }^{12}$. Elas visavam a satisfazer uma curiosidade natural de pessoas que viajavam pouco e desejavam visualizar lugares sobre os quais haviam lido ou ouvido falar.

As vistas surpreendiam pela suntuosidade ou pelo caráter bizarro de certas culturas e civilizações. Contudo, não era apenas o estrangeirismo dos temas que maravilhava os olhos e os sentidos, mas também os efeitos luminosos que
12. Ibidem. Vistas de óptica com efeitos diurnos e noturnos, assim como diferentes modelos de caixas de óptica, podem ser visualizadas no site <http://users.telenet.be/ thomasweynants/vue-optique.html>

Annals of Museu Paulista. v. 18. n.1. Jan. - Jun. 2010. 


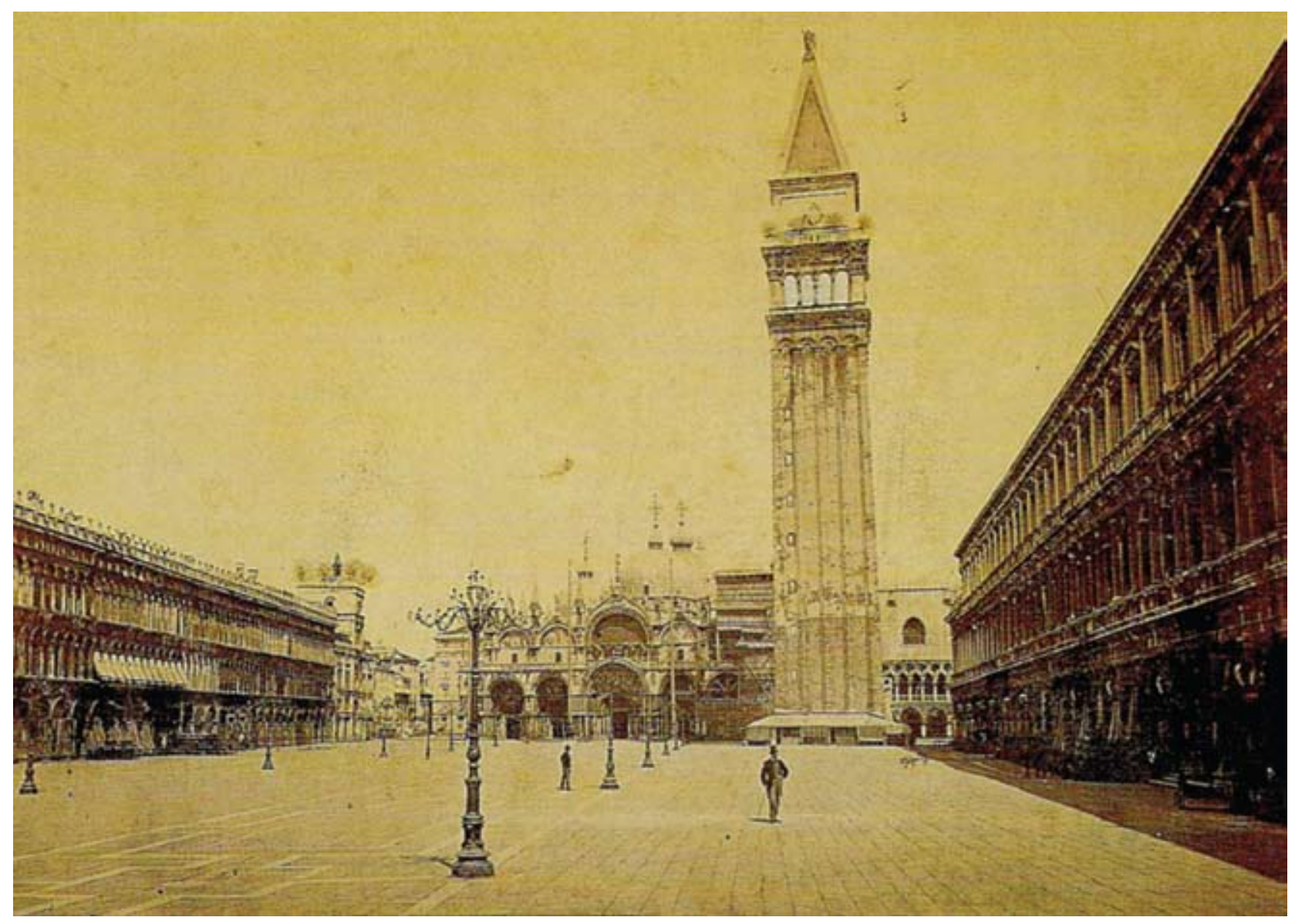

FIGURAS 2 e 3 - Placa de Megaletoscópio. Vista com efeito diurno e noturno. Fotografia em albumina sobre papel com aplicação de cor no verso e perfurações para efeitos luminosos. Praça de São Marcos com igreja. Veneza, Itália, 1875. Acervo dos Musées Royaux d'Art et d'Histoire, Bruxelas. Reproduzida em: DELTOUR-LEVIE, Claudine. Entre photo et cinéma [catálogo de exposição]. Bruxelas: Musées Royaux d'Art et d'Histoire, 2004. p. 42. Cortesia Musées Royaux d'Art et d'Histoire.

muitas dessas imagens proporcionavam. Boa parte das vistas de perspectiva eram objeto de intervenções manuais, recebendo perfurações e recortes, nos quais eram aplicados, no verso, papéis coloridos transparentes. Após, eram submetidas a diferentes formas de iluminação, permitidas pela mobilidade das tampas laterais, superiores e traseiras das caixas de óptica, proporcionando verdadeiro encantamento. A técnica atingiu o seu auge com o Megaletoscópio de Carlo Ponti (1862), espécie de caixa de óptica aperfeiçoada que permitia visualizar vistas originalmente fotográficas com efeitos diurno e noturno, além de ampliação e profundidade, como dão exemplo as Figuras 2 e 3.

Entre 1841 e 1873, ao menos, exibidores itinerantes de caixas e vistas ópticas expuseram as suas imagens em Porto Alegre de forma independente, apresentando dispositivos que rebatizaram como "cosmoramas" e "cicloramas". Diferente daqueles que realizaram espetáculos de projeções, ocupando os teatros locais, os exibidores de caixas de óptica alugaram salas, e nelas abriram 


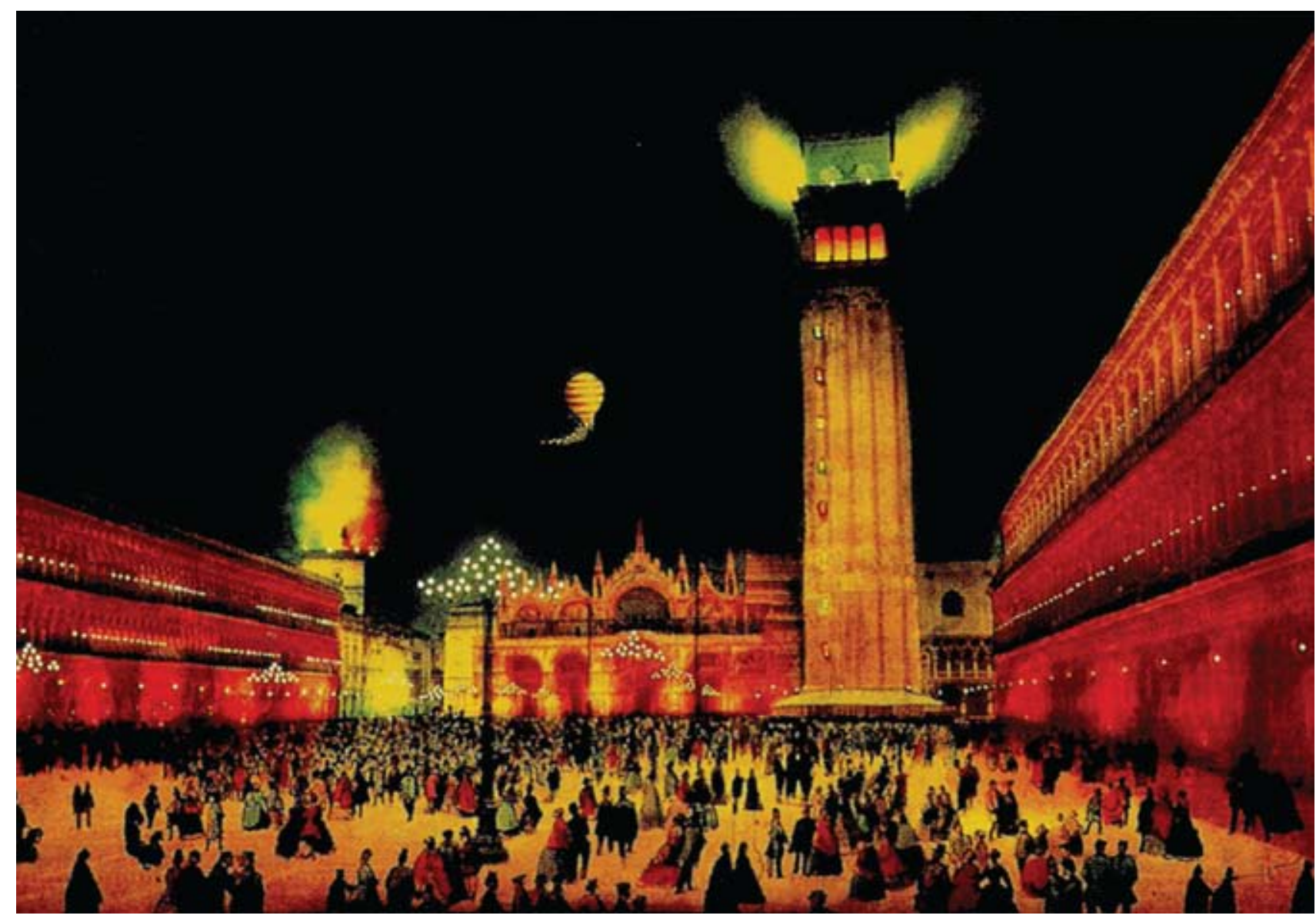

estabelecimentos especializados em diversões ópticas Ali expuseram vistas de diferentes tipos e suportes, isto é, de perspectiva e fotografias estereoscópicas, observáveis através de aparelhos específicos. As suas exposições eram públicas, mas a observação era paga. Como diversões populares e apreciadas que eram, tais aparelhos e gabinetes motivaram inclusive a criação de charges, que foram veiculadas na imprensa local na época. A figura 4 evoca alguns dos interesses temáticos dos contemporâneos com relação às vistas que costumavam ser expostas nos cosmoramas.

Em 1855, funcionou o Gabinete Óptico, em 1861, o Salão Mecânico e, em 1863, o Grande Salão Óptico Mecânico. Tais denominações remetem aos gabinetes de curiosidades dos séculos XVII e XVIII e ao dinâmico complexo das invenções e novidades técnicas que, com suas atrações e artifícios, caracterizava a Europa na época. Os estabelecimentos tinham duração temporária e funcionavam diariamente, à noite, em horários fixos, atualizando semanalmente os seus programas de vistas e exibindo-as com ou sem acompanhamento musical e oral. Abertos para fins de entretenimento, apresentavam-se como uma diversão familiar, estabelecendo preços diferenciados para as entradas de acordo com a faixa etária. Alguns exibidores também comercializaram acessórios e prestaram

Annals of Museu Paulista. v. 18. n.1. Jan. - Jun. 2010. 


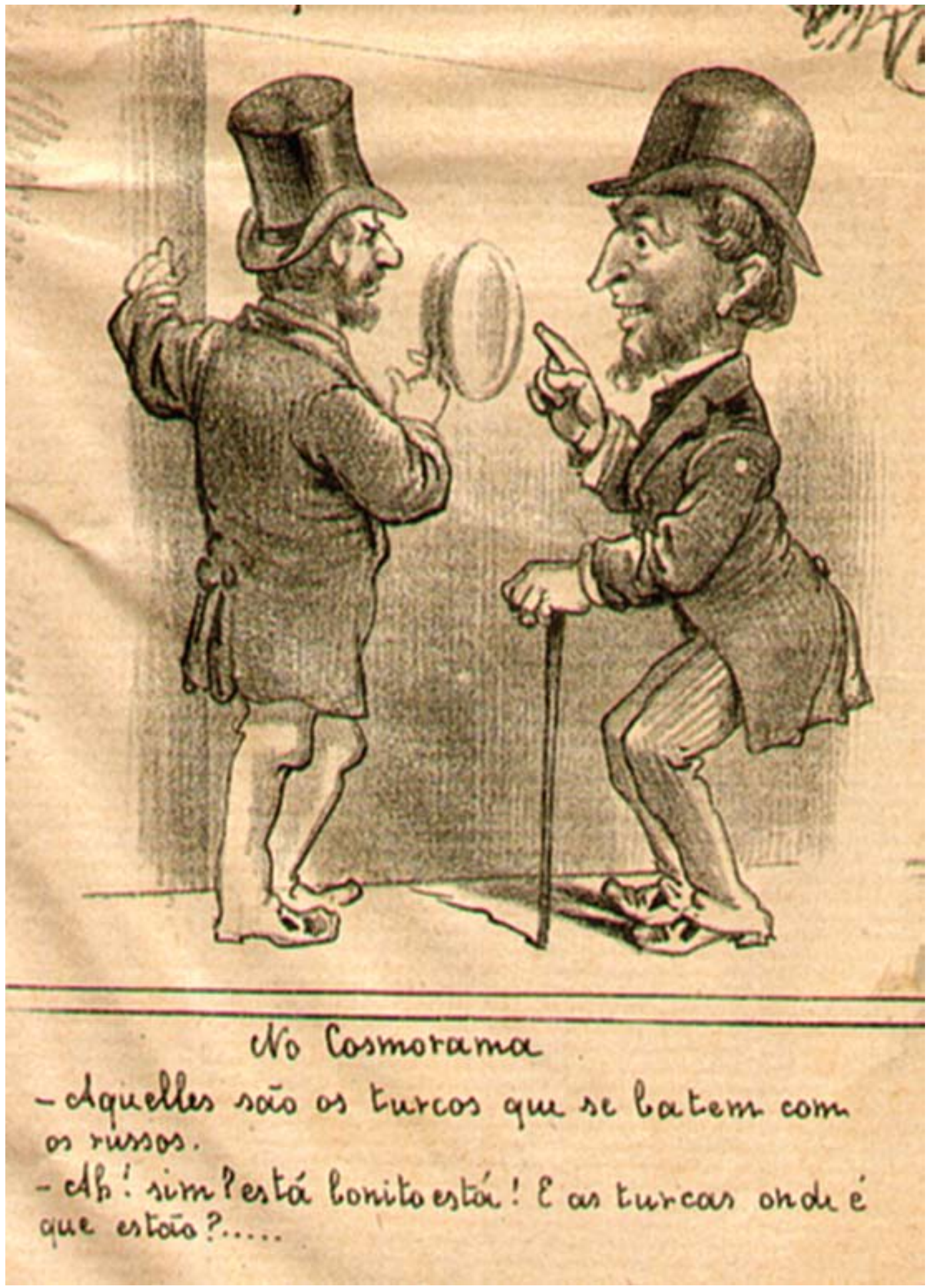

FIGURA 4 - "No Cosmorama". Charge. Autor: Cândido Aragonez de Faria. Jornal O Fígaro, Porto Alegre, ano 1, n. 13, 29/12/1878. Acervo do Instituto Histórico e Geográfico do Rio Grande do Sul-IHGRGS, Porto Alegre. 
serviços, como a pintura de vistas impressas que os apreciadores desse gênero de imagens adquiriam no comércio local. A prática indica que os porto-alegrenses possuíam caixas de óptica portáteis para uso familiar e constituíam coleções privadas de vistas.

A lanterna mágica é um aparelho projetor equipado com lentes e que, numa sala escurecida, mediante o uso de luz artificial, permite a projeção amplificada, sobre um tela ou parede branca, de imagens pintadas sobre uma placa de vidro. Criada em meados do século XVII na Holanda ${ }^{13}$, foi explorada comercialmente por exibidores itinerantes que percorreram a Europa realizando projeções e assim a tornaram cada vez mais popular. Se o princípio da lanterna mágica permaneceu basicamente o mesmo durante os séculos em que foi empregada para divertir e ensinar, tanto lanternas quanto placas de vidro foram recebendo aperfeiçoamentos de sábios e artesãos, que melhoraram a qualidade de suas lentes, fontes energéticas, vistas e suportes, diversificando, ainda, a natureza das imagens projetadas com a incorporação da fotografia.

Confeccionadas em diferentes tamanhos e formatos, as lanternas mágicas tiveram como suas primeiras fontes luminosas as velas e a lâmpada a óleo, cuja luminosidade pouco intensa delimitava o uso do aparelho apenas a salas pequenas, como o exemplifica a figura 5. Na segunda metade do século XIX, com a descoberta de novas fontes energéticas e sua adaptação para fins industriais e comerciais, as lanternas mágicas também passaram a contar com novas fontes de luz, como as lâmpadas de querosene, a luz oxídrica (1870) e a luz elétrica (1890). As duas últimas permitiram que as projeções atingissem o seu mais alto grau de qualidade técnica e artística, passando a ser realizadas em espaços mais amplos e para auditórios maiores.

Industrializadas e comercializadas como aparelhos profissionais e como brinquedos, as lanternas ganharam grande popularidade não somente como meios de viabilização de espetáculos de entretenimento, mas também como instrumentos de informação e formação educacional. A necessidade de lentes cada vez melhores, que evitassem a deformação das imagens e permitissem maior nitidez de contornos e cores, também foi uma exigência colocada pela proliferação dos espetáculos de projeções ópticas e pelo crescimento da demanda por aparelhos profissionais, mais qualificados e condizentes com as novas expectativas do público. A lanterna triunial representada pela figura 6 dá mostras do aperfeiçoamento alcançado pelos projetores do gênero, oferecendo novos e criativos recursos para os projecionistas mais habilidosos.

Até o momento em que foi possível fixar fotografias em placas de vidro (década de 1850) e desenvolver a cromolitografia (década de 1870) 14, as imagens projetadas pelas lanternas eram ilustrações em miniatura, pintadas à mão sobre placas de vidro, produzidas artesanal e individualmente. Por serem de confecção demorada e trabalhosa, eram caras. $\bigcirc$ trabalho devia ser minucioso e preciso, pois o menor defeito ficava evidenciado claramente no momento da projeção ampliada. Em geral, tais diapositivos eram peças circulares de vidro, montadas sobre quadros de madeira, cujas dimensões foram padronizadas mundialmente. Suas imagens tinham por temas guerras europeias, vistas turísticas, expedições a
13. A lanterna mágica foi descrita pelo matemático e físico holandês Christiaan Huygens (1629-1695) em 1664, mas só recebeu esse nome em 1668, tendo sido produzida a partir de uma série de conhecimentos já acumulados nos terrenos da física $\mathrm{e}$ da óptica. Athanase Kircher, que costuma ser apontado como o seu inventor, descreveu-a apenas em 1671 e sem a precisão do verdadeiro criador. Cf. Laurent Mannoni (2003, p. 62).

14. O seu produto direto foi a decalcomania, criada na Alemanha para baratear a confecção das placas de vidro de lanterna. A técnica, que teve rápida expansão, permitia a compra de tiras de papel com desenhos em cores transparentes, para destacá-los e colá-los nas placas de vidro. $\mathrm{O}$ procedimento facilitou a produção e ampliou a comercialização de placas e lanternas destinadas ao uso infantil e familiar doméstico. Os temas dos decalques eram variados: paisagens, marinhas, lendas e mitos, sátiras, diabruras, grandes descobertas, viagens, séries infantis, como as aventuras de Robinson Crusoé, contos dos Irmãos Grimm e de Perrault, entre outros. Ver Claudine Deltour-Levie (2004). 


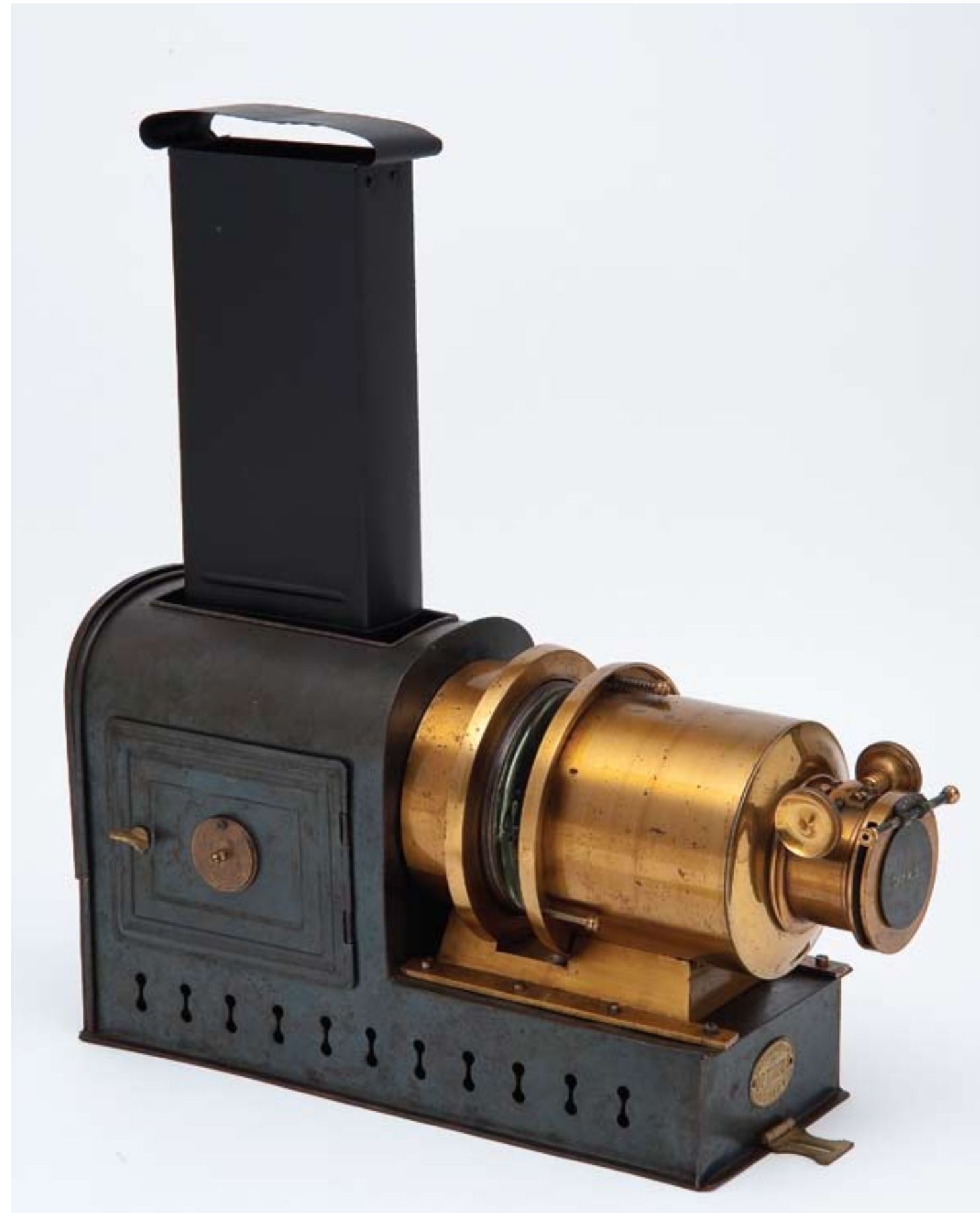

FIGURA 5 - Lanterna Mágica. Londres, Parkson And Co., modelo Optimus, c. 1870. $22 \times 41 \times 13 \mathrm{~cm}$. Fonte energética: óleo de parafina. Apresenta cabeçote de cobre e uma chaminé de altura regulável. Pertenceu ao fotógrafo Militão Augusto de Azevedo (1837-1905). Acervo do Museu Paulista da Universidade de São Paulo, São Paulo. Fotografia de José Rosael. Cortesia do Museu Paulista da USP. 


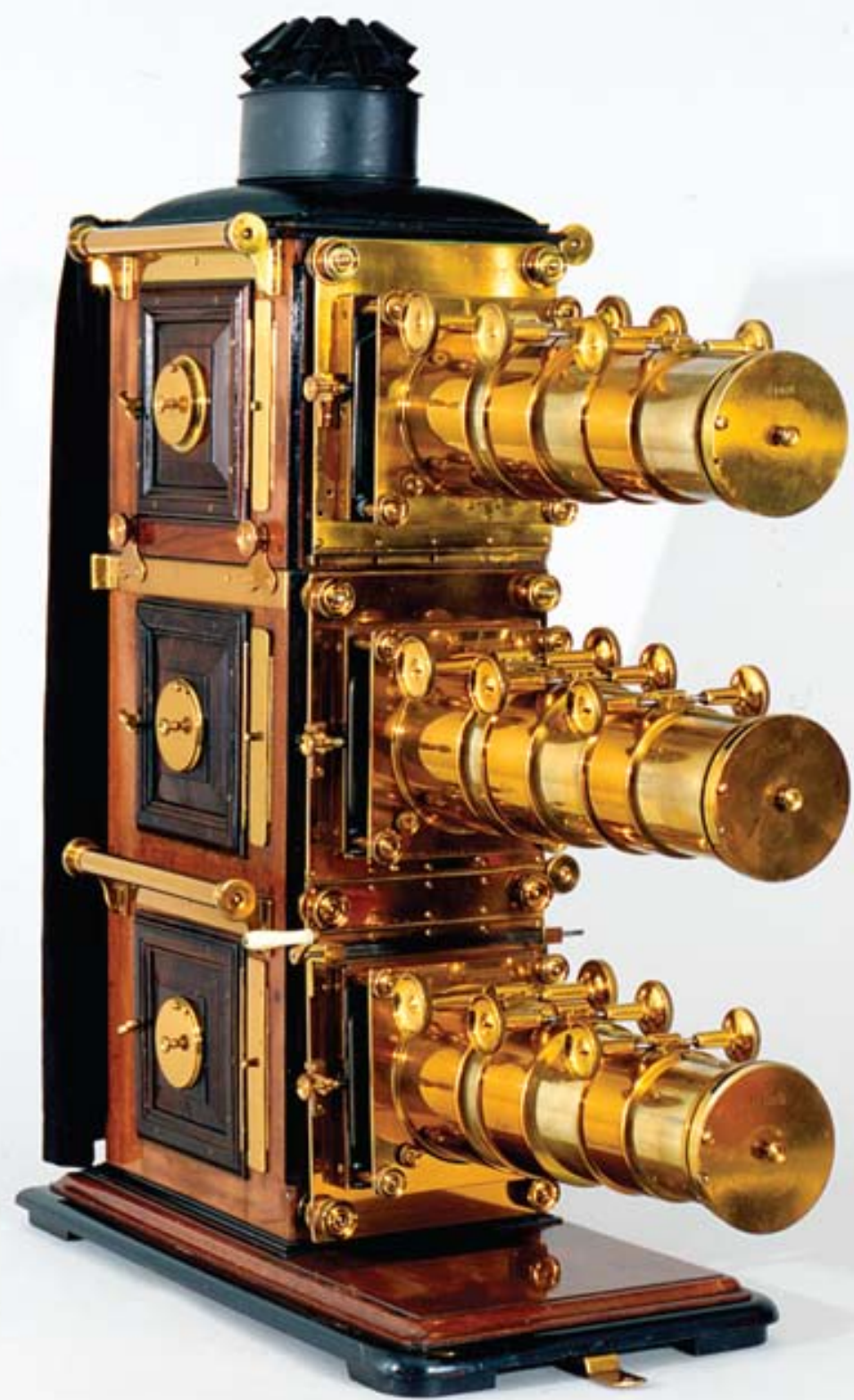

FIGURA 6 - Tripla lanterna de projeção para vistas dissolventes. The Climax Tri-Unial Riley Brothers. Londres, Alfred Wrench et Riley Brothers, 1888. $66 \times 50,5 \times 45 \mathrm{~cm}$. Acervo da Cinemateca Francesa, Paris. Fotografia de Stéphane Dabrowski. Reproduzida em MANONNI, L. e CAMPAGNONI, D. P. (Org.). Lanterne magique et film peint, 400 ans de cinema. Catálogo. Paris: Éditions de La Martinière/ La Cinémathèque Française, 2009, p. 216. Cortesia Cinemateca Francesa 
lugares exóticos (selvas e regiões polares), histórias fabulosas e humorísticas, contos de fada, trechos de óperas, temas religiosos e científicos (anatomia, botânica, zoologia, arquitetura, história, astronomia, geografia), retratos de personalidades, temas grotescos e de terror, cenas da vida cotidiana etc. A placa representada na figura 7 foi produzida a partir de uma litografia de 1844, utilizada originalmente como ilustração em um livro sobre o cotidiano dos caçadores das pradarias norteamericanas. Como outras imagens do gênero produzidas e exibidas no século XIX, também esta contribuiu para a popularização de obras literárias e artísticas, proporcionando encantamento e formação aos seus espectadores.

As placas e suas imagens foram objeto de pesquisas sucessivas, que buscavam proporcionar projeções mais nítidas e com efeitos diversos, inclusive de movimento. Para tal fim, foram desenvolvidos mecanismos e acessórios que permitiam a projeção de ilustraçães com movimentos simples e efeitos de dissolução. Outra linha de pesquisa permitiu que, pela época do surgimento do cinematógrafo, as lanternas já projetassem fotografias e estereoscopias em P\&B e com aplicações de cores, sendo que boa parte dos suportes das placas deste gênero já apresentava formato quadrangular, como a figura 8 permite constatar. Como essa, boa parte das placas de lanterna mágica para projeção, assim como das vistas ópticas

FIGURA 7 - Placa para lanterna mágica. Hunting Buffaloes. Pintada à mão e atribuída a William Robert Hill. Londres, Royal Polytechnic, c. 1860 $27,8 \times 27,8 \mathrm{~cm}$. Acervo da Cinemateca Francesa, Paris. Fotografia de Stéphane Dabrowski. Reproduzida em MANONNI, L. e CAMPAGNONI, D. P. (Org.). Lanterne magique et film peint, 400 ans de cinema. Catálogo. Paris: Éditions de La Martinière/ La Cinémathèque Française, 2009, p. 74. Cortesia Cinemateca Francesa

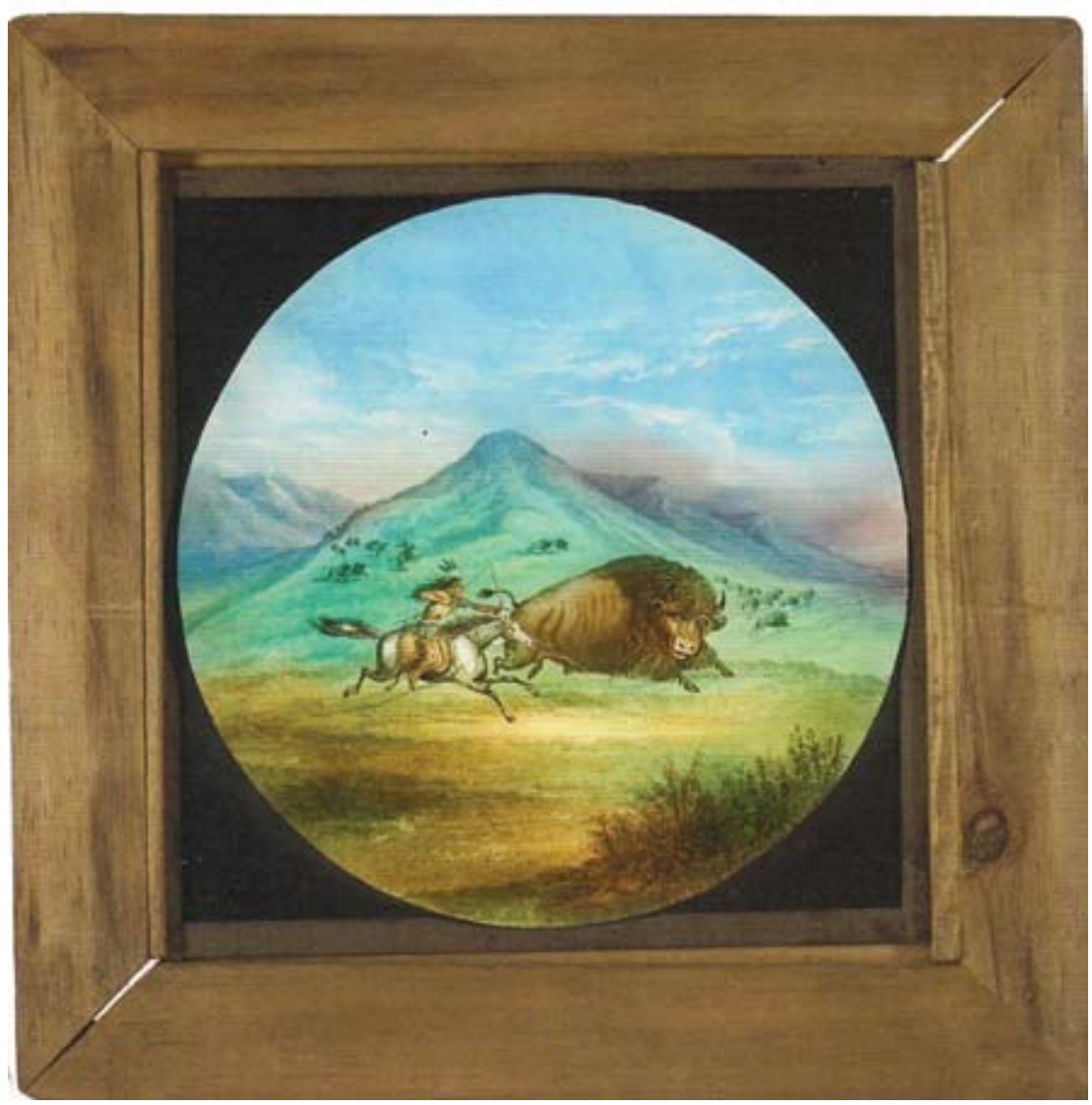

Anais do Museu Paulista.v. 18. n.1. jan.jun. 2010. 
produzidas na segunda metade do século XIX, tiveram matrizes fotográficas, que também deram origem a álbuns de vistas e cartões postais

Os espetáculos de projeções de lanterna mágica (1861-1896)

Os espetáculos públicos de projeções foram apreciados pelos portoalegrenses a partir de $1861^{15}$, ao menos, sendo as lanternas mágicas e suas vistas exibidas majoritariamente para fins de entretenimento e no Theatro São Pedro ( 1858). Não foram abertas na capital gaúcha, no século XIX, salas especializadas em projeções luminosas, como foi corrente na Inglaterra e na França. $\bigcirc$ teatro se tornou o lugar por excelência da sua exibição também por ter sido o palco habitual dos espetáculos de prestidigitação ${ }^{16}$ e variedades, aos quais as projeções foram incorporadas como atrações complementares. Entre 1901 e 1908, o São Pedro voltaria a ser preferencialmente ocupado para espetáculos de projeções, mas autônomas e cinematográficas.
15. Ver Athos Damasceno Ferreira (1956).

16. A prestidigitação, também conhecida como ilusionismo e mágica, foi um gênero de espetáculo muito apreciado, tanto em Porto Alegre como em boa parte do mundo, na segunda metade do século XIX, contando com nomes de grande reputação mundial.

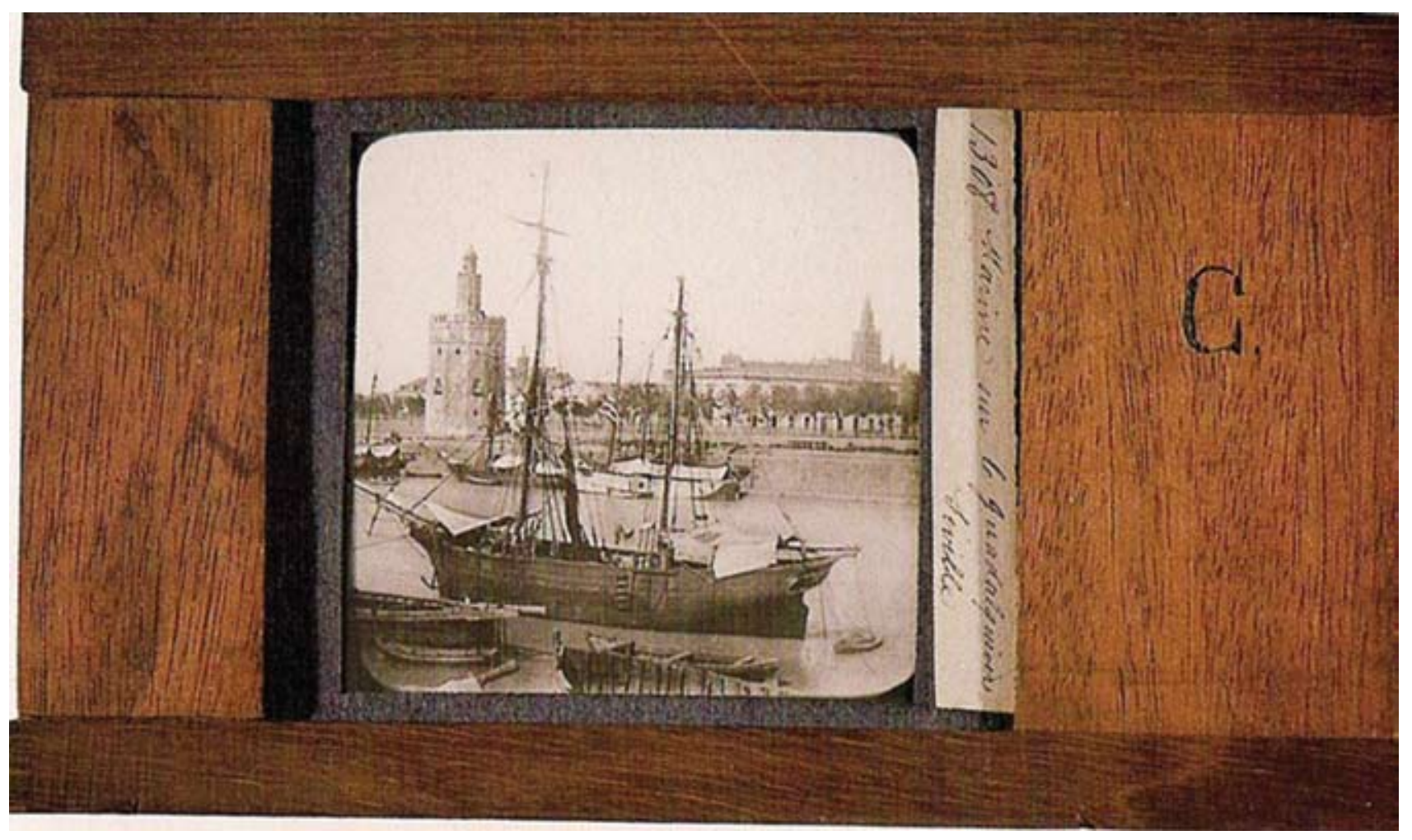

FIGURA 8 - Placa para lanterna mágica. Turismo: El Guadalquivir (Sevilha). Fotografia P\&B sobre vidro. 10,3 x 17,8cm. França, final século XIX. Acervo do Museu do Cinema da Filmoteca Espanhola, Madri. Reproduzida em: 50 años de la Filmoteca Española. El cine español en los años 50 [catálogo]. Madri: Sociedad Estatal de Commemoraciones Culturales, 2003, p. 113. Cortesia Filmoteca Espanhola. 
17. Ver Tom Gunning (1996).

18. Idem, p. 27.

19. Ibidem.

20. As lanternas mágicas comumente eram manuseadas em meio ao público, sendo que a distância entre o projetor e a tela dependia da potência de sua fonte luminosa e da qualidade do espelho côncavo que ajudava a concentrar essa luz em direção à objetiva. Segundo Laurent Mannoni (2003), essa extensão podia ser de 6 a 9 metros ou até mais, observando que, quanto maior fosse a distância, maior seria também a imagem final reproduzida, como ocorre com os projetores de slides, já defasados tecnologicamente, dos quais as lanternas mágicas foram os ancestrais diretos.

Nesse espaço de consagrada consideração pública, tanto a prestidigitação quanto as projeções ópticas acabariam por se impor e ganhar alguma notoriedade como gêneros de entretenimento, angariando a atenção de um público mais exigente e cosmopolita. No entanto, nunca chegaram a rivalizar, em prestígio e em valor social e artístico, com as companhias dramáticas e líricas. ○ seu interesse maior devia equilibrar-se, como bem observou Tom Gunning, entre os esforços de uma ciência empírica, cada vez mais "desconfiada da evidência visual" 17 , para se contrapor a uma audiência popular, cada vez mais fascinada com espetáculos que exibiam imagens mecânicas.

Analisando a grande popularidade da óptica como forma de entretenimento científico a partir do final do século XVII, o historiador norte-americano observou que o emaranhado de "modernos modos de percepção e novas tecnologias" 18 que caracterizou o contexto das diversões na segunda metade do século XIX e deu origem ao cinema resultou da confluência entre uma "antiga tradição de mágica imagística" e um "nascente iluminismo científico"19. Era um contexto em que oscilava-se entre o desejo de produzir maravilhas e o interesse em desmistificar superstições e charlatanismos por meio de demonstrações científicas.

$\bigcirc$ próprio inventor da lanterna mágica evitou ser associado ao seu invento, evidenciando uma preocupação em separar a ciência dos resultados de sua apropriação para fins de entretenimento. Esta postura, porém, foi contemporânea de outra, que procurou valorizar algumas das diversões ópticas exatamente pela sua origem científica. Tal ambiguidade também foi comum entre os prestidigitadores que realizaram projeções. Enquanto alguns alimentaram o mistério, ocultando os meios de produção mecânica dos seus truques, outros se esforçaram em afastar as projeções de qualquer aparência de bruxaria ou mágica, revelando um espírito científico crescente.

Também em Porto Alegre esse traço foi visível. Localmente, a incorporação dos aparelhos ópticos de projeção a espetáculos que reuniam outros números de ilusionismo foi operada segundo duas finalidades distintas. A primeira, e mais comum, consistia em apresentar as projeções como uma atração extra, destinada a dar maior duração, atualidade, variedade e valor artístico e cultural aos espetáculos. Da mesma forma, o projetor de nome mirabolante era propagado com destaque e mantido acessível aos espectadores, que podiam apreciar tanto as projeções como a invenção científica que as propiciava ${ }^{20}$. Nessas projeções, eram privilegiadas imagens de grande beleza, que oferecessem aos espectadores um entretenimento prazeroso e instrutivo, e uma experiência lúdica e onírica. Daí o predomínio das vistas de temática turística e artística, mas também daquelas que ilustravam pequenas narrativas das mais diversas origens, baseadas tanto em fábulas e fantasias quanto nos clássicos da literatura laica e religiosa.

A segunda orientação obedecia ao interesse e/ou necessidade de empregar tais dispositivos como meios de viabilização mecânica de certos efeitos e truques, comumente relacionados às ciências ocultas. Neste caso, o seu uso não era revelado, preocupando-se o ilusionista em ocultá-lo, a fim de manter o 
mistério e aumentar a tensão entre o auditório, correspondendo ao gosto pela ilusão e pelos espetáculos de sensações.

Nas décadas de 1860 e 1870, as projeções realizadas na capital gaúcha estiveram associadas aos espetáculos de prestidigitação e ilusionismo, sendo exibidas como atração complementar e final dos programas. A partir do final do período, outras atrações, de outros gêneros, como o circense, seriam incorporadas pelos próprios prestidigitadores, além da ventriloquia e da música, dando lugar às primeiras companhias de variedades, ainda fortemente associadas às artes da ilusão óptica. Com tais iniciativas, tais profissionais procuraram inicialmente preservar sua arte em meio às transformações das práticas espetaculares e às novas exigências dos espectadores, cada vez mais orientadas por expectativas de variedade e atualidade. A incorporação gradual de atrações que produzissem efeitos visuais e sonoros inusitados, enfatizando as experimentações e o humor, contribuiu para diversificar os seus espetáculos, nos quais continuaram a participar as projeções, alargando o seu grau de interesse junto a um público mais amplo e heterogêneo. Mais raros foram os espetáculos exclusivamente de projeções, realizados por exibidores autônomos.

Noturnos e de duração prolongada, os espetáculos incluíam intervalos e eram acessíveis mediante ingressos de valores diferenciados, correspondentes às distintas qualidades das acomodações dos teatros. No final da década de 1880, certas práticas promocionais começaram a ser empreendidas pelos diretores das companhias artísticas, inclusive das que exibiam as projeções ópticas, como a organização de espetáculos especiais denominados "de gala" e "da moda". Nessas ocasiões, costumava-se reunir a totalidade dos artistas do grupo e incorporar ainda uma orquestra, iniciativa que visava a distinguir o espetáculo como um "acontecimento artístico", conferindo-the maior sofisticação. Embora não fossem alterados os preços das entradas, tais "funções" acabavam sendo apropriadas como oportunidades de distinção social, atraindo aos teatros um público mais elitizado.

Os profissionais que apresentaram as projeções luminosas na cidade não eram exatamente lanternistas, mas artistas nacionais e estrangeiros itinerantes, que incluíram Porto Alegre no roteiro de suas turnês. Por essa razão, eles promoveram exibições de caráter esporádico e temporário. Para viabilizar as projeções, empregaram modelos aperfeiçoados de lanterna mágica, de grandes dimensões e complexidade, mas sempre ocultos sob designações fantasiosas: Megascópio egípcio (1861 e 1878); Poliorama fantasmagórico (1863, 1887); Poliorama elétrico (1882); Poliorama universal (1896); Silforama (1888, 1893, 1895, 1896, 1898); Diafanorama ou Diaforama (1875, 1897); e Kaleidoscópio gigante (1880, 1883, 1887). Tal diversidade de denominações correspondeu, muito provavelmente, às necessidades de distinção promocional e comercial dos exibidores frente aos concorrentes congêneres e teve por fim renovar o grau de interesse da atração junto ao público pelo viés da "novidade".

Ao longo da segunda metade do século XIX, houve uma única ocasião em que a imprensa porto-alegrense se referiu a um aparelho de projeção exibido publicamente como lanterna mágica (1880). Neste caso, porém, pretendeu-se depreciar o respectivo espetáculo de projeções e o seu exibidor, o que endossa

Annals of Museu Paulista. v. 18. n.1. Jan. - Jun. 2010. 
21. Ver Maria Cristina Miran da da Silva (2006).

22. Os espetáculos de Fantasmagoria foram explorados em Paris a partir de $\mathbf{1 7 9 2}$, por Philidor e depois por Robertson, entre outros. Neles, eram realizadas sessões de projeções animadas, em cores e sonoras, causando pavor por mostrar, em retroprojeção móvel, mas oculta, pequenos esquetes macabros, com vistas pintadas à mão ou objetos opacos, que cresciam ou diminuíam diante do espectador à medida que a lanterna se aproximava ou distanciava da tela atrás da qual estava escondida. Neste tipo de espetáculo, costumava-se invocar espíritos e espectros, "materializados" a partir da projeção de imagens em ambientes cuidadosamente preparados com cenários, objetos, efeitos sonoros e olfativos, constituí dos de modo a intensificar o clima de mistério e a sensação de suspense junto ao público. Paradoxalmente, o "show" era antecedido do aviso de que os "fantasmas" projetados eram "meras aplicações das leis da óptica e da perspectiva", isto é, não eram reais, mas apenas efeitos de ilusão óptica.

23. Cf. Athos Damasceno Ferreira (1956, p. 159).

24. Cf. Antônio Jesus Pfeil (1999, p. 28) a percepção de que os nomes fantasiosos sob os quais eram ocultas as lanternas aperfeiçoadas exibidas nos grandes teatros atendiam também a uma necessidade de enobrecer e profissionalizar o seu uso, bem como o espetáculo por elas proporcionado. Buscava-se demarcar e distinguir o âmbito profissional e público de exploração das projeções daquele amador e doméstico, onde "lanterna mágica" definia um dispositivo de confecção e funcionamento mais simples, portátil e manejável inclusive pelas crianças, mas que não proporcionava os mesmos surpreendentes e grandiosos efeitos visuais.

Por outro lado, tais denominações diferentes permitem observar as especificidades da apropriação regional e local dos aparelhos de projeção óptica e a inscrição dessa experiência no movimento mundial das transformações da cultura visual da época. Nesse sentido, observou-se igualmente que, em Porto Alegre, foi comum os exibidores se autopromoverem, associando às vistas de lanterna mágica o qualificativo "dissolventes", o que indicaria que elas eram projetadas por lanternas de duas ou três objetivas e com efeitos de dissolução ou fusão.

No Rio de Janeiro, diferentemente, a lanterna mágica ficou associada ao termo "fantasmagoria"21, embora este designasse apenas uma modalidade específica e complexa de espetáculo de projeção por lanterna mágica ${ }^{22}$. Essa segunda associação foi observada em Porto Alegre, em 1888, em uma única ocasião, mas igualmente sem corresponder aos espetáculos originais, conforme realizados na Europa. Em outras palavras, embora seja possível que a maior parte dos exibidores tenha apresentado localmente vistas dissolutivas, também deve ser considerado que o termo "dissolventes" pode ter sido adotado localmente com intuito apenas promocional. Ou seja, destinado a endossar a natureza da atração, como espetáculo de projeção de imagens, mas não necessariamente com efeitos de dissolução.

A seguir são relacionadas sucintamente as principais características da exibição das projeções luminosas realizadas localmente entre 1861 e 1896. Na medida do possível, identificam-se os modos de exibição das vistas, os gêneros e temáticas das imagens projetadas, as iniciativas que buscaram incrementar os espetáculos, e o grau de receptividade do público a este conjunto. Tais informações visam a contribuir, a partir das escassas referências hoje disponíveis, para uma percepção mais aproximada acerca de um processo que foi mais amplo, rico e complexo do que os registros que deixou ou que foram dele preservados.

A começar pelos prestidigitadores que ofereceram as projeções como atração complementar aos números de sua especialidade, verificou-se que foi nos espetáculos do físico franco-inglês Dr. Mailhor Lohlian que os porto-alegrenses assistiram pela primeira vez à "reprodução de numerosas vistas dissolventes e animadas a maravilhosos efeitos e transmutações momentâneas"23. Realizados no Theatro São Pedro em 1875, contaram com um Diafanorama, por meio do qual o exibidor teria projetado uma coleção de, ao menos, 50 vistas dissolventes, renovando-as ao longo da temporada. Entre elas, constavam "retratos dos célebres republicanos Garibaldi e Gambetta" e das "batalhas de 1870 e 1871"24. 
A técnica das vistas dissolventes (vues fondantes ou dissolving views) foi a mais apreciada e a que mais possibilidades abriu aos usos da lanterna mágica. Inicialmente realizada por meio de duas ou mais lanternas, colocadas ao lado ou acima uma da outra, a projeção passou a ser viabilizada, a partir de 1852, por meio de uma única lanterna com duas ou três objetivas (biunial e triunial, respectivamente). Em qualquer dos casos, os focos deveriam estar concentrados num mesmo ponto, fazendo convergir os seus eixos ópticos. A finalidade era produzir discos de luz coincidentes sobre a tela e permitir a lenta fusão de versões alternativas de uma mesma imagem ou de imagens diferentes numa só. As lentes do projetor eram equipadas com obturadores mecânicos, conhecidos como "olho de gato", que auxiliavam a revelar ou ocultar alternadamente cada uma das objetivas e das imagens das placas. Entre os temas mais comuns das vistas dissolventes, estiveram versões diurnas e noturnas de uma mesma cena ou a transformação de uma paisagem ao longo das estações do ano, como se pode observar nas placas das figuras 9 e 10. A referência à "animação" das vistas pode indicar que Lohlian também dispunha de placas mecânicas, dispositivos criados ainda no início do XVIII, que permitiam a projeção de imagens com movimentos simples e repetitivos ${ }^{25}$. $\bigcirc$ que se sabe, porém, é que seus espetáculos foram divulgados como distração agradável e familiar, com o que atendiam ao crescente interesse pelas formas de entretenimento leves e descomprometidas que, no final da década de 1870, estimulou o surgimento das primeiras companhias de variedades.

A primeira companhia do gênero a se apresentar na cidade foi trazida pelo prestidigitador A. J. D. Wallace, que fez temporada no Theatro São Pedro em 1878. Os programas dos seus espetáculos reuniam números de prestidigitação, ventriloquia, ginástica, acrobacia e projeções ópticas pelo "Megascópio Egípcio ou Aparelho de Vistas Dissolutivas"26. Em alguns programas, as projeções foram substituídas pela apresentação da "paródia" da "famosa experiência que Cagliostro27 chamou Espelho Negro"28, na qual - ilusionista prometia fazer "aparecer o retrato dos defuntos que o público pedir, assim como de pessoas ausentes e presentes no espetáculo"29. $\bigcirc$ anúncio respectivo acrescentava tratar-se de um "estranho fenômeno, que apresenta uma aparição sobrenatural"30.

Movidos por intuitos publicitários, boa parte dos ilusionistas da época, tanto brasileiros quanto europeus, não temiam associar seus nomes ao de Cagliostro e identificar seus espetáculos com a reputação de tão controversa figura. Ao contrário, a aposta na confusão de fronteiras entre ciência e espetáculo não era despropositada ${ }^{31}$. Wallace, inclusive, preferiu não explicar o sobrenatural como efeito de truques de óptica, mantendo a dúvida quanto ao real caráter da atração, diferente do que fariam os seus sucessores nos anos seguintes. $\bigcirc$ número era desconhecido localmente e, por isso, foi descrito pela imprensa somente após ter sido realizado. No relato, destacou-se a participação da plateia na sugestão dos nomes das "aparições" e o sucesso do truque - "um trabalho excelente, cheio de
25. As placas mecânicas consistiam basicamente na sobreposição de duas placas de vidro, sendo a primeira fixa e a segunda circular móvel, ambas montadas sobre um mesmo quadro de madeira. Uma imagem parcial era pintada sobre o diapositivo fixo e as partes restantes sobre o diapositivo rotativo. Quando o mecanismo era acionado, geralmente por uma manivela, o vidro circular começava a girar e as partes das imagens pintadas nos dois vidros se mesclavam, criando um efeito de movimento, como por exemplo de um moinho cujas pás giram. A partir desse sistema, foram criados outros similares, produzindo novos efeitos. Cf. Laurent Mannoni, (2003, p.130). Uma série de exemplos, inclusive reproduzindo os efeitos que a sua movimentação produzia na projeção, podem ser visualizados no item "lantern slides" do site holandês $<$ http://www.luikerwaal. com>.

26. Ver anúncio em $A$ Refor$m a$, Porto Alegre, ano 10, n. 4, p. 3, 5 jan. 1878.

27. Cagliostro foi o pseudônimo adotado pelo alquimista siciliano Giuseppe Balsamo (1743-1795). Ele foi um dos mais famosos representantes das ciências ocultas de sua época, adquirindo fortuna com a venda de poções, elixires e "filtros de amor", mas terminando preso, em função de acusações de charlatanismo e feitiçaria.

28. Cf. A Reforma, Porto Alegre, ano 10, n. 14, p. 4, 17 jan. 1878.

29. Ibidem.

30. Cf. Mercantil, Porto Alegre, ano 5, n. 13, p. 2, 16 jan. 1878.

31. VerTom Gunning (1996). 


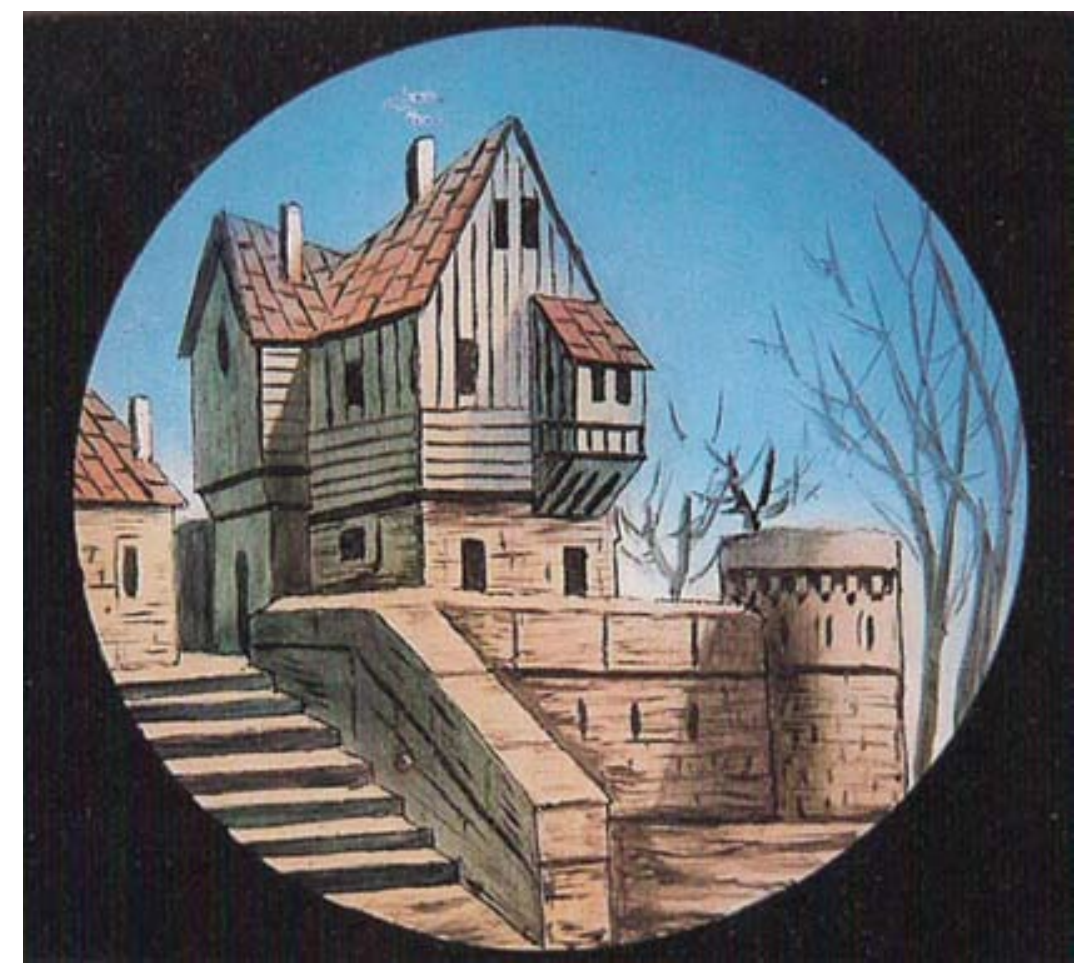

FIGURAS 9 e 10 - Placas para lanterna mágica. Vistas dissolutivas. Outono e Inverno, respectivamente. $10 \times 9 \mathrm{~cm}$ cada. Final séc. XIX. Acervo do Museu do Cinema da Filmoteca Espanhola, Madri. Reproduzida em: 50 años de la Filmoteca Española. El cine español en los años 50 [catálogo]. Madri: Sociedad Estatal de Commemoraciones Culturales, 2003, p. 112. Cortesia Filmoteca Espanhola.

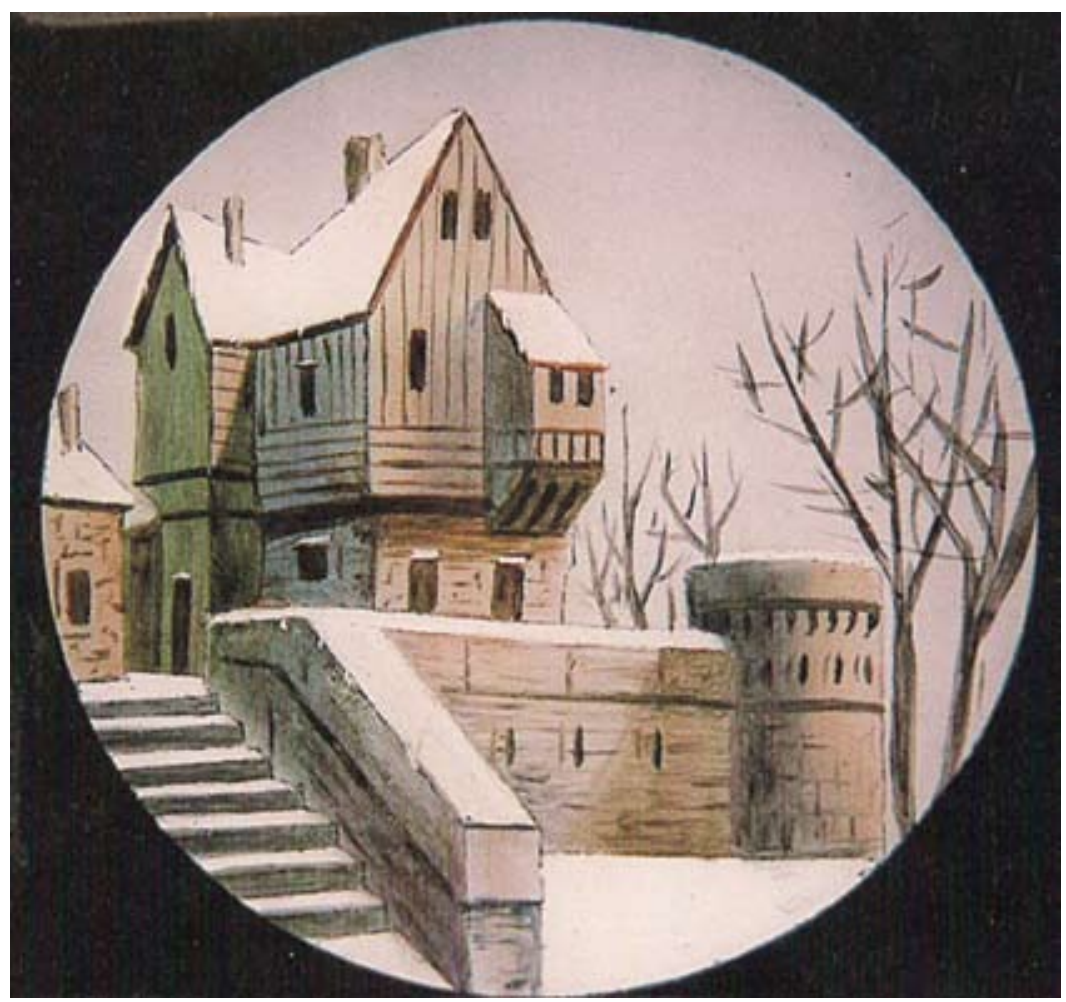


muita ilusão" - junto ao público, que o aplaudiu, aproveitando a ocasião para demonstrar sua adesão ou antipatia aos retratos das personalidades exibidas.

A ênfase no efeito ilusório do número revela, ao menos, a compreensão dos jornalistas a respeito de sua natureza, identificada com as técnicas e mecanismos de ilusão óptica e seus artifícios, e não, com o sobrenatural. Outros relatos afastam a ideia de que a atração tenha provocado medo ou pavor entre o público ${ }^{32}$, destacando, ao contrário, a sua "curiosidade e efeitos surpreendentes" 33 . Embora não haja referência ao uso de aparelhos ópticos, é muito provável que tenha sido empregada alguma forma de projeção oculta, uma variante da fantasmagoria. Em certa modalidade, costumava-se exibir, a partir dos mesmos princípios e dentro do mesmo clima de suspense e mistério, imagens de personalidades mortas ou vivas. Para tal, o exibidor procurava obter antecipadamente alguma fotografia ou pintura retratando a pessoa indicada para, então, reproduzir a sua figura sobre uma placa de vidro, que podia ser projetada sobre fumaça ou outro suporte, ampliando os efeitos fantasmagóricos ${ }^{34}$.

Com base em informações encontradas na bibliografia estrangeira sobre as experiências do gênero e nos comentários da imprensa local aos espetáculos, acredita-se que Wallace tenha praticado algo semelhante, sendo provável que possuísse um bom acervo de placas representando alguns dos defuntos famosos e das personalidades vivas que povoavam o imaginário da época. Entre os retratos que exibiu no tal "Espelho negro", que pode ter sido uma tela preparada para assumir esse papel, constavam aqueles de "Thiers, Saldanha Marinho, Herval, Silveira Martins e Frei Caetano de Troyna"35, todos aplaudidos com entusiasmo, com exceção daquele do imperador D.Pedro Il, que foi recebido com uma forte pateada, isto é, batidas no chão com os pés.

Esta segunda forma de participação do público, que demonstra a interatividade entre o apresentador, as imagens e os espectadores, foi comum nos espetáculos do gênero. Eles eram comumente abertos pelos próprios ilusionistas, também mestres-de-cerimônia, que costumavam apresentar os truques em meio a uma fala, de preferência bem humorada. $\bigcirc$ traço era volta e meia elogiado; ou até mesmo criticado, no caso da prolixidade excessiva de certos profissionais. $\bigcirc$ acompanhamento oral das projeções, por sua vez, foi anunciado apenas pelos exibidores que as apresentaram como atrações exclusivas, embora se acredite que a prática tenha sido corrente.

Manifestações motivadas por razões políticas e desencadeadas a partir da projeção de imagens de personagens históricos e autoridades contemporâneas, observadas pela primeira vez nessa temporada, reapareceriam nos anos seguintes e sobretudo no período da exibição cinematográfica itinerante. $\bigcirc$ fato é que as vistas fixas dessa temática continuaram sendo exibidas naqueles espetáculos, porém segundo uma proposta diversa, em projeção aberta. No caso de Wallace, a reação durou "os poucos minutos" em que o teatro esteve "em trevas" 36 . A mesma escuridão que impediu a identificação dos pateadores deve
32. Cf. Mercantil, Porto Alegre, ano 5 , n. 13 , p. 2,16 jan 1878 .

33. Cf. A Reforma, Porto Alegre, ano 10, n. 14, p. 4, 17 jan. 1878.

34. Philidor, o inventor do número, tinha o cuidado de avisar na imprensa que aqueles que desejassem ver pessoas vivas ou mortas do seu círculo deveriam avisá-lo de véspera. De forma astuciosa ou amigável, ele obtinha o retrato da pessoa em questão e mandava pintá-lo nas placas de vidro, projetando sua imagem em tamanho natural para os parentes e amigos do representado. Para isso tinha à disposição um bom pintor de placas. Cf. Laurent Mannoni (2003, p. 156).

35. Cf. Mercantil, Porto Alegre, ano 5 , n. 15 , p. 1,18 jan. 1878 .

36. Cf. A Reforma, Porto Alegre, ano 10, n. 17, p. 1, 20 jan. 1878. 
37. Cf. A Reforma, Porto Alegre, ano 10, n. 16, p. 3 , 19 jan. 1878.

38. O microscópio de projeção foi construído pelo físico francês Jacques Charles em 1783. Tratava-se de uma volumosa lanterna mágica aperfeiçoada, à qual foi adaptado um mecanismo de microscópio. Cf. Laurent Mannoni (2003, p.86-87; 140; 268).

39. Cf. anúncio em Mercantil, Porto Alegre, ano 7, n. 237, p. 3, 19 out. 1880 . ter auxiliado o prestidigitador a ocultar os meios de viabilização das suas "aparições".

Um outro aspecto que merece destaque - e que foi referido com naturalidade pela imprensa - diz respeito à presença das crianças no teatro, tendo, uma delas, ajudado o ilusionista a sortear as figuras sugeridas pelo público para as aparições. De fato, apesar da deficiente iluminação de que a cidade gozava no período e de serem majoritariamente noturnas as funções dadas nos centros de diversões, são numerosas as indicações revelando que crianças frequentavam esses espetáculos, sobretudo aqueles de projeções ópticas e prestidigitação. Mesmo no teatro lírico e dramático, observou-se a presença de crianças pequenas e de colo entre o público. Em suas primeiras décadas de existência, também o cinema não faria qualquer objeção à presença infantil. Ao contrário, até a estimularia com uma série de promoções.

No que respeita às projeções tradicionais de vistas, divulgadas explicitamente como tais, foram realizadas apenas no terceiro e quarto espetáculos de Wallace e, tal qual ocorreu com o "Espelho negro", como número final do programa. A atração, apresentada como "Megascópio Egípcio ou As vistas dissolutivas, finalizando pelo quadro Gerard, o afamado caçador de leões" 37 , evidenciava o aparelho projetor e o efeito das imagens, citando o que deve ter sido o título de uma das histórias ilustradas pelas projeções, prática muito corrente nos espetáculos do gênero. $\bigcirc$ silêncio da imprensa sobre a qualidade dessa projeção e de sua recepção pelo público pode estar relacionado, entre outras razões, ao fato das vistas não apresentarem originalidade e/ou beleza, atributos elogiados em outras temporadas do gênero, mas também à concorrência que lhes fez o inédito número do "Espelho Negro".

Propondo um modo diverso de exibição, em 1880 o professor alemão David J. Hofmann realizou uma temporada exclusivamente de projeções ópticas no Theatro de Variedades (1 879) com uma "Lanterna-microscópio"38. Para divulgar as exibições, o lanternista mandou publicar anúncios na imprensa e imprimir folhetos avulsos com os seus respectivos programas, os quais foram distribuídos pelas ruas. Nesses materiais, prometia-se um "deslumbrante espetáculo", "nunca visto nesta capital", no qual seria empregado um aperfeiçoado "microscopo". Este projetaria "representações da história natural, geografia, zoologia, astronomia, anatomia, etc., etc., por meio de preparos naturais e artificiais, que se têm engrandecido até 20 milhões de vezes"39. Também apresentaria um número musical como atração extra.

Durante as projeções, o professor Hofmann explicaria as imagens mostradas, dissertando sobre as suas temáticas. No entanto, embora planejasse realizar cerca de cinco espetáculos, precisou abreviar sua temporada, em razão do repúdio do público à exibição, partilhado pela imprensa e divulgado após o segundo espetáculo. É possível que tal reação já tivesse se verificado após a estreia, considerando-se a nota que passou a ser divulgada com insistência antes do espetáculo seguinte, informando aos interessados que o exibidor não repetiria os programas e não exibiria "Cosmorama". Já nos anúncios iniciais, Hofmann havia avisava que suas exibições contariam sempre com programas novos. Quanto 
ao Cosmorama, costumava denominar, no estrangeiro e no meio local, outro gênero de entretenimento óptico, relacionado à exposição e observação de vistas panorâmicas e turísticas de cidades em caixas de óptica. É possível que, neste caso, tratando-se de um espetáculo de projeções, o termo concentrasse a ideia daquela temática, visto que foi a sua ausência no acervo do exibidor que provocou a frustração dos espectadores. $\bigcirc$ aviso parece, assim, enfatizar o esclarecimento, também presente nos primeiros anúncios do exibidor, acerca dos assuntos das imagens que pretendia projetar, devendo prevenir os interessados contra as expectativas de visualização de imagens comuns aos cosmoramas.

fato é que Hofmann ofereceu um espetáculo de projeções ópticas, mas empregando um modelo aperfeiçoado de lanterna mágica, capaz de ampliar como um microscópio placas especialmente preparadas, com temática específica e de caráter instrutivo-pedagógico. $\bigcirc$ comentário publicado na imprensa após as duas primeiras exibições demonstra que ele cumpriu essas promessas:

\begin{abstract}
As maravilhas que o senhor professor da lanterna mágica anunciou e exibiu sábado, no Theatro de Variedades, apresentando ao respeitável [público] piolhos, pulgas, macacos, carrapatos e em tamanho superior dez milhões de vezes! ao seu estado natural, foram de um efeito tal, que as 40 ou 50 pessoas que assistiram à exibição patearam-no solenemente. A isto é que se pode chamar uma verdadeira extorsão às algibeiras do próximo. $\bigcirc$ professor Hofmann julgava talvez que vinha conviver entre montanheses do Tirol, onde a cítara e as suas maravilhas são quiçá muito apreciadas... Pois enganou-se redondamente; o público de Porto Alegre provou que não era beócio, reagindo contra semelhante charlatanismo. Bem feito!" 40 .
\end{abstract}

No entanto, impressiona a forte reação de rejeição do público local à temática das imagens projetadas, e também ao número musical. Os espectadores sentiram-se logrados, como se vê, embora o exibidor tenha exibido as suas placas "científicas" de grande ampliação. Talvez a expectativa criada fosse por animais de outras espécies e não insetos, que parecem ter repugnado e ofendido os presentes. Os usos educativos das projeções luminosas foram descobertos e valorizados desde cedo entre alguns povos europeus, como os alemães, enquanto que na França as lanternas mágicas foram consagradas predominantemente ao entretenimento. Hofmann representava aquela primeira tendência, mas talvez ela não estivesse entre as preferências dos porto-alegrenses que frequentavam espetáculos de projeções ópticas. Afinal, o caso parece indicar uma infeliz experiência de desencontro entre oferta e demanda.

A crítica sofrida por Hoffman propiciou uma das raras ocasiões em que a lanterna mágica foi referida com o seu nome original na imprensa porto-alegrense ao longo da segunda metade do século XIX. Tanto nessa ocasião como em 1897, quando outro exibidor foi criticado pela sofrível qualidade de suas projeções de vistas fixas, o termo foi empregado em tom depreciativo, visando a desvalorizar as projeções e o seu exibidor ao colocá-lo no mesmo nível dos amadores de todo tipo, que faziam uso de lanternas mágicas simples, de uso doméstico.

Em 1882, o prestidigitador barcelonês J. Jam y Nurat realizaria uma temporada de espetáculos nos mesmos moldes do colega Lohlian e no mesmo 
41. Cf. A Reforma, Porto Alegre, ano 14, n. 61, p. 3 , 16 mar. 1882.

42. As placas de rosácea ou cromatrópios foram inventadas em torno de 1840 pelo inglês Henry Langdon Childe. O sistema consistia em sobrepor duas placas circulares que, quando acionadas por uma manivela, giravam uma sobre a outra, simultaneamente, mas em sentido contrário, através de engrenagens dentadas. Eram geralmente pintadas com desenhos abstratos, representando espirais ou motivos geométricos, cuja projeção resultava em efeitos de interferência e fascinantes jogos de forma e cor. Era um trabalho artesanal, cujo resultado, mesmo limitado a movimentos repetitivos, encantava os espectadores. Cf. Claudine Deltour-Levie (2004, p. 13 e 21).

43. Cf. anúncio em $A$ Refor$m a$, Porto Alegre, ano 19, $\mathrm{n}$. 122, p. 4, 2 jun. 1887.

44. Cf. A Reforma, Porto Alegre, ano 19, n. 124, p. 2, 4 jun. 1887.
Theatro São Pedro. Além dos números de prestidigitação, empreendeu a "surpreendente exibição do Grande Poliorama Elétrico", apresentando "quadros dissolventes representando com toda naturalidade os países mais nomeados em ambos os mundos: monumentos, praças, ruas, cascatas, belas artes, etc." ${ }^{1}$. Neste caso, apesar da referência às vistas dissolutivas, os temas citados não correspondem àqueles que costumavam ser projetados com efeitos de dissolução, ou seja, que representavam uma mudança temporal. Isso significa que alguns dos exibidores que atribuíram suas vistas como "dissolventes" podem ter exibido apenas vistas comuns, designando-as como tal a fim de aumentar as expectativas do público sobre a qualidade do espetáculo.

Este exibidor merece destaque também por ter promovido um espetáculo "de gala", dedicando-o ao presidente da Província, à Sociedade (abolicionista) Rio Branco e aos alunos da Escola Militar, iniciativa que visava a atrair à função membros de todas estas pequenas "comunidades", habituais frequentadores do teatro, na verdade, dando formalidade ao espetáculo. Como viria a tornar-se de praxe em promoções dessa natureza, independente do gênero espetacular, o programa seria aberto por uma orquestra, prosseguindo com outras atrações e encerrando-se com as projeções.

No mesmo ano, outro prestidigitador, Henrique Lavigne, projetou no Theatro São Pedro, e segundo o mesmo modo de exibição, vistas da Inglaterra, França, Itália, Egito, Palestina e Índia. $\bigcirc$ nome do aparelho empregado, "Kaleidoscópio gigante", sinaliza também a possibilidade de que o exibidor dispusesse de placas do gênero cromatrópio, que proporcionavam a projeção de imagens abstratas e coloridas, móveis, cujos efeitos eram semelhantes àqueles das imagens visualizadas através dos caleidoscópios portáteis comuns ${ }^{42}$.

Lavigne voltou à cidade em 1887 e desta vez se apresentou no Theatro de Variedades, finalizando os seus espetáculos com o "Poliorama gigante de 21 vistas" e um número "nunca visto na cidade", intitulado as "maravilhosas Fontaines de Versailles". Antes de estreá-lo, o artista fez questão de avisar ao público que não o confundisse com a atração homônima recentemente apresentada no Theatro São Pedro pelo Conde Patrizio, que consistia na reprodução real de uma fonte de água "colorida" no palco do teatro, criada a partir de dispositivos mecânicos, hidráulicos e elétricos ${ }^{43}$.

Segundo relatou posteriormente a imprensa, o número das fontes de Lavigne agradou deveras ao público, "sobressaindo o último quadro - Gruta onde descansa Diana depois da caça - que é de um efeito deslumbrante" 44 . Considerando as explicações do artista, a referência a um "quadro" com o título citado e o contexto de sua exibição, é provável que se tratasse de um conjunto temático de placas de lanterna do gênero vistas dissolventes, com efeitos de movimento, mostrando, inclusive, as fontes secas e a jorrar, alternadamente.

O prestidigitador Conde Patrizio de Castiglioni, acima referido, realizou três temporadas em Porto Alegre: em 1880, 1883 e 1887. A segunda delas foi - grande destaque do ano no meio espetacular local. A sua companhia de variedades, a Patrizio's llusionist Company, era especializada em espetáculos de prestidigitação, ilusionismo, óptica e equilibrismo, e reunia vários componentes. 
A trupe realizou doze espetáculos na cidade, noturnos e praticamente diários, descansando nas segundas-feiras. Ocupando predominantemente o Theatro São Pedro, mas também o Theatro de Variedades, fez enorme sucesso e deixou ótima impressão entre os espectadores locais, em função das deslumbrantes vistas dissolventes que projetou e dos números acrobáticos e de contorcionismo que apresentou. Por melhores que tenham sido as projeções de vistas, porém, o seu maior sucesso de público e crítica foi o número da "Evocação dos fantásticos e imponentes espectros vivos e impalpáveis" 45 .

Elogiada unanimemente como "surpreendente efeito de óptica"46, a atração foi pela primeira vez apresentada ao público local. Não se tratava de um número de projeções ópticas, mas de reflexão por espelhos, descrito em detalhes pela imprensa após repetidas apresentações, tanto em função do seu ineditismo, quanto do interesse em valorizar os alardeados esforços e gastos implicados em sua execução ${ }^{47}$. Na verdade, fazia-se uso de uma lanterna mágica para realizá-lo, mas isso em função da necessidade de uma potente fonte luminosa, como a luz Drummond (usada por Patrizio) ou luz oxídrica. O projetor ficava oculto sob o palco e iluminava um ator, também oculto, cuja imagem era refletida de um espelho a outro, operação mantida invisível aos espectadores, até refletir-se no palco, onde um ator "de carne e osso" contracenaria com o "fantasma" resultante. No anúncio correspondente, veiculado por Patrizio, informava-se que as "aparições" seriam exibidas em "cenas", isto é, pequenos esquetes, que provavelmente contextualizavam as imagens como personagens de uma narrativa, como fazia Henri Robin (1 805-1875), o criador do espetáculo das "aparições espectrais" ${ }^{\prime 4}$. Os seus títulos revelam temáticas que eram conformes às práticas: "O busto insequestrável", "A desposada", "O pesadelo", "Aparição do Diabo" e "Luta com a morte"49.

A temporada de Patrizio foi acompanhada por intensa cobertura da imprensa, aliada a um significativo investimento em publicidade impressa. Os programas eram sempre divididos em quatro partes, sendo encerrados, alternadamente, com o número dos espectros ou com as projeções ópticas, realizadas por meio do "Kaleidoscópio gigante", sendo exibidas vistas de "viagens artísticas nas principais cidades do mundo / Ao reino das cores" ${ }^{50}$. Ou seja, panoramas de cidades com seus principais pontos turísticos e monumentos; e, talvez, placas animadas do tipo cromatrópios. A imprensa qualificou a atração como "soberba" por concentrar "quadros de beleza incontestável"51.

Patrizio também promoveu uma "extraordinária e maravilhosa função de gala", dando continuidade a uma prática que já vinha sendo empreendida no meio espetacular local. Neste caso em particular, a orquestra contratada para abrilhantar a função preencheu os intervalos do programa com números musicais executados ao vivo. Este seria, de resto, o modo de incorporação do elemento sonoro musical nos espetáculos de projeções realizados em Porto Alegre até 1908, caracterizando uma participação pontual das orquestras e bandas militares nos programas, de caráter promocional, restrita a ocasiões especiais.

Outra promoção de Patrizio foi a "grande função da moda", que buscava novamente concentrar, do ponto de vista das práticas sociais, certas
45. Cf. anúncio em Mercantil, Porto Alegre, ano 10, $\mathrm{n}$. 151, p. 3, 4 jul. 1883.

46. Cf. Gazeta de Porto Alegre - Folba da Tarde, Porto Alegre, ano 5, n. 192, p. 2, 22 ago. 1883; e Mercantil, Porto Alegre, ano 10, n. 192, p. 2, 22 ago. 1883

47. Cf. A Reforma, Porto Alegre, ano 15 , n. 189 , p. 2 , 24 ago. 1883.

48. Cf. Laurent Mannoni (2001, p. 253-256).

49. Cf. Mercantil, Porto Alegre, ano 10, n. 192 , p. 3, 22 ago. 1883; e anúncio em $\mathrm{Ga}$ zeta de Porto Alegre - Folha da Tarde, Porto Alegre, ano 5, n. 192, p. 3, 22 ago. 1883. Duas imagens distintas ilustrando o processo óptico podem ser observadas em $<$ http://users.telenet.be/tho$\mathrm{m}$ a s w e y a n t s / p e ppers-ghost.html>

50. Cf. A Reforma, Porto Alegre, ano 15, n. 185, p. 3, 19 ago. 1883 .

51. Cf. Mercantil, Porto Alegre, ano 10, n. 190, p. 2,20 ago. 1883 . 
52. Cf. Gazeta de Porto Alegre - Folba da Tarde, Porto Alegre, ano 5, p. 3, 27 ago. 1883.

53. Entre 1838 e 1876 , destacou-se em Londres a Royal Polytechnic Institution, que foi tanto um local de entretenimento quanto de ensino. Além de seu rico gabinete de curiosidades e do auditório reservado aos espetáculos de prestidigitação e física, contava com um teatro, que era reservado às projeções de lanterna mágica e aos espetáculos de fantasmagoria. Também fez sucesso na instituição o microscópio de projeção, mas a atração mais apreciada era a projeção de vistas dissolventes. Uma boa parte das placas de vidro da Royal foi conservada, demonstrando que elas estiveram entre aquelas de maior qualidade artística já produzidas. Cf. Laurent Mannoni (2003, p. 270).

54. Cf. Mercantil, Porto Alegre, ano 14, n. 75 , p. 3, 9 abr. 1887.

55. Cf. A Reforma, Porto Alegre, ano 19 , n. 80, p. 3 13 abr. 1887.

56. Cf. anúncio em Mercantil, Porto Alegre, ano 15, n. 225 , p. 3,6 out. 1888 expectativas do público, reproduzindo localmente um uso que também vinha sendo verificado no Rio de Janeiro e em Buenos Aires. Essa função também contou com a execução de números musicais ao vivo nos intervalos do programa. Por ocasião da "função de despedida", "beneficente" ao prestidigitador, outra praxe habitual da época, anunciou-se que seria projetada uma "grande coleção de quadros dissolventes, representando as mais formosas obras mestras e vistas do Universo, dirigidas pelo professor Robertson de Londres" e "A gota d'água ou os mistérios do mundo invisível"52.

A referência ao famoso cientista-lanternista Robertson, que, se não inventou a fantasmagoria, soube extrair desse método de projeção todas as suas possibilidades enquanto espetáculo, teve evidente intenção de valorizar a atração. O mesmo pode ser dito sobre a remissão à Inglaterra, que, na época, era de fato uma referência fortíssima em matéria de projeções de lanterna mágica, juntamente com a França e a Alemanha ${ }^{53}$. Os títulos dos jogos de vistas anunciados por Patrizio são, por sua vez, facilmente identificados como peças capazes de maravilhar os espectadores, proporcionando tanto distração quanto informação, além de demonstrar familiaridade temática com as vistas londrinas.

Em 1887, Patrizio faria sua terceira temporada de exibições em Porto Alegre, apresentando vários dos números exibidos em temporadas anteriores, inclusive as projeções ópticas pelo "Poliorama (Kaleidoscópio gigante)" e os Espectros. Os espetáculos foram novamente realizados no Theatro São Pedro e encerrados pelas projeções, prometendo-se ao público a oportunidade de "uma viagem fantástica ao redor do mundo em 30 minutos" 54 . Esta se estenderia "a todos os mundos conhecidos e desconhecidos. Europa, América, Ásia, África, Oriente-Ocidente completos. Os palácios faraônicos, as maravilhas da criação, China e Rússia interiores, os principais museus do mundo, Reinos fantásticos, Paraísos, Soberanos, As mil e uma noites em ação, etc." 55 .

Diferentemente das temporadas anteriores, nesta deu-se maior ênfase às projeções, insistindo-se na novidade das vistas, talvez porque, frente à ausência de novidades, houvessem assumido maior importância nos programas. Pela temática turística das imagens, é bastante provável que as vistas fossem fotográficas e que esta viagem imaginária contasse com explicações orais do prestidigitador, no papel de cicerone virtual. Afinal, o conjunto reunia imagens de lugares desconhecidos e exóticos, assim como de objetos e obras de arte de museus estrangeiros, possivelmente vistos pela primeira vez por boa parte dos espectadores.

No ano seguinte, voltaram a ser realizados na cidade espetáculos exclusivamente de projeções. Apresentada como "Theatro Mágico Phantasmagoria", a diversão foi estabelecida por um lanternista não-identificado no Salão Preussler (antiga rua das Flores, 34, atual rua Siqueira Campos). Apesar da denominação, nas únicas três funções realizadas foram projetadas as tradicionais vistas de lanterna mágica "instrutivas e recreativas", representando "os mais afamados edifícios, paisagens, fenômenos naturais, fatos históricos, experiências químicas, intermezzos burlescos, etc." ${ }^{56}$. A nota acrescentava que as projeções seguiam o "sistema do distinto professor Tessié du Mothay, em cópia 
natural, com os efeitos das mais brilhantes cores. Transmutações maravilhosas, movimentos com as explicações relativas" 57 .

Como se pode verificar, era diversificado o acervo de placas deste exibidor, podendo incluir vistas fotográficas pintadas, além de vistas dissolutivas. O sistema citado, por sua vez, dizia respeito ao emprego de luz oxídrica como fonte luminosa do aparelho, o que garantia uma ótima projeção ${ }^{58}$. $\bigcirc$ fato de o "Theatro Mágico" ter sido exibido num salão particular, provavelmente de menores dimensões que os teatros locais, aumenta as chances de que essas exibições tenham alcançado grande qualidade técnica e beleza. Também desta vez elas foram acompanhadas de explicações orais.

A última temporada de projeções de lanterna mágica realizada em Porto Alegre num contexto cultural do qual ainda não faziam parte o cinematógrafo e suas vistas animadas foi organizada pelo prestidigitador e ventríloquo Curvelo D'Avila. Os seus espetáculos aconteceram no Theatro São Pedro, em 1896, e reuniam números de prestidigitação, ventriloquia e projeções ópticas pelo "Poliorama Universal". As vistas foram exibidas no final dos programas, resumindose os comentários da imprensa à observação de ser o projetor "lindo e prende[r] a atenção do espectador pelas variadas e soberbas vistas de que dispõe" 59 .

\section{advento do cinematógrafo e a animação das projeções (1 896)}

Em 1896, foram apresentadas aos porto-alegrenses as projeções cinematográficas. Elas foram exibidas como uma novidade técnica que era, também, uma nova atração, mas ainda sem futuro definido. Tratava-se de uma modalidade de projeção fundada num novo gênero de imagens, na época denominadas "fotografias ou vistas animadas". A partir do momento em que tais imagens começaram a ser exibidas localmente, aquelas peculiares à tradição lanternista passaram a ser designadas, em distinção, como "vistas fixas". Tal diferenciação foi estabelecida pelos contemporâneos a partir dos materiais visuais que thes eram familiares e foi rapidamente assimilada, acompanhando a exibição dos dois tipos de vistas nos espetáculos de projeções oferecidos na cidade a partir de então60.

Em novembro de 1896, dois demonstradores diferentes, Francisco De Paola e Georges Renouleau, trouxeram à cidade projetores cinematográficos e os mantiveram em funcionamento diário e noturno durante cerca de vinte dias ${ }^{61}$. Os seus espetáculos, exclusivamente de projeções cinematog ráficas, foram realizados de forma inovadora, considerando-se o modo de exibição das vistas e os locais escolhidos para empreendê-los. As projeções foram realizadas em sessões curtas e sucessivas em duas salas vizinhas, alugadas e adaptadas pelos exibidores para a atividade, na mesma quadra da rua dos Andradas, a mais central da cidade.

Antes de conhecerem pessoalmente o cinematógrafo e suas imagens, porém, os porto-alegrenses deles tiveram notícia pelos jornais locais, que publicaram impressões sobre as primeiras projeções cinematográficas realizadas no Rio de
57. Ibidem.

58. Tessié du Mothay foi um engenheiro francês que, na década de 1860, aperfeiçoou o sistema de produção de energia luminosa por meio do gás oxi-hidrogênio, descoberto na Inglaterra em 1826 . A luz oxídrica foi empregada nas lanternas mágicas e também na iluminação de edifícios públicos e interiores de teatros. Até a invenção da luz elétrica, foi a mais intensa das fontes luminosas conhecidas e a mais utilizada pelos lanternistas que, na segunda metade do século XIX, pretendiam projetar para grandes auditórios. Contudo, era considerada perigosa, pois o lanternista necessitava carregar consigo uma bomba de oxigênio e acontecia de essa bomba explodir em plena projeção. Essa foi a causa do famoso incêndio do Bazar de la Charité, ocorrido em Paris em 1897.

59. Cf. Mercantil. Orgão Federalista, Porto Alegre, ano 22, n. 207, p. 2, 7 set. 1896.

60. O termo "fita" começaria a ser empregado em Porto Alegre a partir de 1908 e logo a seguir seria alternado com outro, film, que só se afirmaria no pós-guerra 1914-1918, acompanhando o rápido crescimento da filmografia norte-americana no mercado local.

61. Os introdutores do cinematógrafo em Porto Alegre não eram artistas, mas pertenciam ao grupo dos primeiros exploradores que apresentaram a novidade no Brasil. Francisco de Paola era um exibidor e explorador de novidades técnicas, sendo conhecido na cidade como demonstrador de fonógrafos, atividade que o trouxe a Porto Alegre em 1892, $1894 \mathrm{e}$ 1895; cf. Alice D. Trusz (2008, p. 96). Georges Renouleau havia deixado temporariamente a sua profissão de fotógrafo, com atelier fixo em São Paulo, para aventurar-se na exploração do cine- 
matógrafo. Também ele era conhecido na capital gaúcha, onde havia exercido sua especialidade em 1878; cf. Athos Damasceno Ferreira (1974, p. 5).

62. Ver Ominiographo, em Mercantil. Órgão Federalista. Porto Alegre, ano 22, n. 172 , p. 1, 28 jul. 1896; matéria reproduzida a partir da folha carioca Jornal do Comércio, p. 1, 21 jun. 1896, e transcrita integralmente em Vicente de Paula Araújo (1976, p. 74).

63. Cf. Rick Altman (1995, p. 65-69; 2005, p. 90-91). O projetor empregado pelos irmãos Lumière nas primeiras sessões públicas do cinematógrafo, realizadas em Paris em dezembro de 1895 por exemplo, compreendia uma lanterna mágica produzida por Alfred Molteni (1837-1907), um dos dois maiores fabricantes franceses de lanternas de projeção profissionais das últimas décadas do século XIX. Esta lanterna "vinha montada sobre quatro pés de cobre, base de mogno e tubo óptico também de cobre, e tinha por fonte de luz o gás de oxi-hidrogênio ou lâmpada de arco", isto é, elétrica; cf. Laurent Mannoni (2003, p. 287)

64. Ver Tom Gunning (1996).

65. Além dos espetáculos de projeção de vistas de lanterna mágica, os parisienses costumavam frequentar regularmente, desde 1892 , as sessões de projeção de desenhos animados chamadas Pantomimas Luminosas, realizadas por Émile Reynaud no Musée Grévin, em Paris, com enorme sucesso de público; cf. Laurent Mannoni (2003, p. 359)
Janeiro e em Lisboa. A fim de expressarem a novidade das imagens e a qualidade diversa da experiência sensível que proporcionavam, os autores dessas matérias fizeram uso de expressões relativas às práticas contemporâneas suas e de seus leitores. Enquanto o projetor foi referido como "maravilhosa lanterna mágica da ciência", as imagens projetadas, ainda sem estatuto legal próprio, foram identificadas como "série enorme de fotografias" que permitia observar figuras em movimento, "acusando-se em um relevo extraordinário, dando magnífica impressão da vida real"62. Essa era, reconhecidamente, a novidade trazida pelos filmes, a reprodução do movimento (reconstituído ilusoriamente na projeção) a partir do registro fragmentado da passagem do tempo, possibilitado pela fotografia instantânea, verdadeiro fundamento das pesquisas que levaram ao cinema.

Embora a organização peculiar das salas especializadas em projeções tenha merecido descrição nesses relatos inaugurais, o mesmo não ocorreu com o projetor propriamente dito. A razão é que, até 1912, aproximadamente, o projetor cinematográfico não era um aparelho independente, mas um dispositivo composto de duas partes. De um lado, preservava uma lanterna mágica tradicional, concentrando a fonte de luz artificial necessária às projeções, e o passa-vistas, que dava suporte às placas de vidro. De outro, agregava um mecanismo, desenvolvido pelos irmãos Lumière, chamado "cabeça de movimento", cuja função era desenrolar os filmes flexíveis diante da objetiva ${ }^{63}$ Essa configuração técnica bifuncional dos projetores foi uma das características que facilitou a alternância constante entre as vistas fixas e as animadas em boa parte dos espetáculos de projeções realizados em diferentes partes do mundo, inclusive em Porto Alegre, durante a primeira década da história do cinema). As figuras 11 e 12 permitem observar as características técnicas assinaladas em dois projetores de épocas distintas, 1897 e 1912, evidenciando o caráter dinâmico das práticas culturais como modos de fazer históricos.

Se tais aspectos relativizam a novidade do cinema como espetáculo, por outro lado, é inegável que ele foi um fenômeno novo e particular quando surgiv, embora compartilhasse uma série de características comuns com outras formas de representação da época. A sua invenção e disseminação ocorreram no contexto da complexa e rica cultura visual que vinha sendo dinamizada por um grande fascínio pelos jogos, truques eaparelhos óptico-mecânicos desenvolvidos em torno das possibilidades de iludir o olho. Como tal, o cinema foi uma nova expressão de uma tendência de consumo que dominou o século anterior e um novo expoente da adaptação das descobertas científicas para fins de entretenimento ${ }^{64}$.

A sua novidade mais evidente concentrava-se, de fato, na técnica de produção e reprodução de imagens, conquistada a partir da contribuição de cientistas e inventores que se sucederam em aperfeiçoar cada descoberta, até que os irmãos Lumière, entre outros, decidissem transformá-la num espetáculo coletivo de projeções. A iniciativa foi estimulada pela feliz exploração comercial que Thomas Edison já vinha fazendo dos filmes através dos seus quinetoscópios de observação individual (1894), considerando também o interesse do público da época pelos espetáculos de projeções luminosas ${ }^{65}$. Assim procedendo, os franceses 


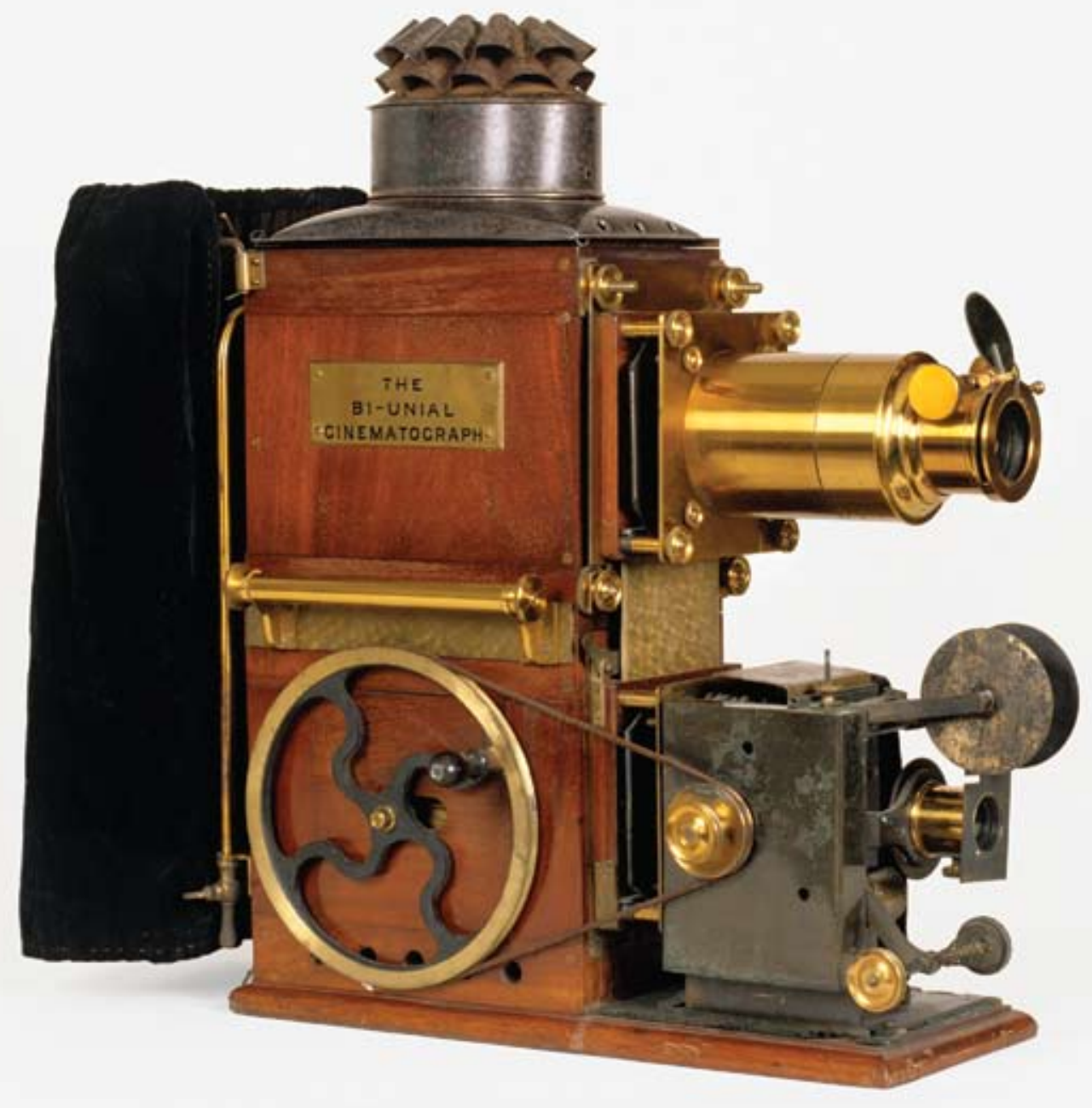

FIGURA 11 - The Wrench Cinematograph, aparelho projetor bifuncional, simultaneamente lanterna mágica e cinematógrafo. Londres, John Wrench, c. 1897. $66 \times 71 \times 27 \mathrm{~cm}$. Acervo da Cinemateca Francesa, Paris. Fotografia de Stéphane Dabrowski. Repriduzida em: MANONNI, L. e CAMPAGNONI, D. P. (Org.). Lanterne magique et film peint, 400 ans de cinema [catálogo]. Paris: Éditions de La Martinière/ La Cinémathèque Française, 2009, p. 256. Cortesia Cinemateca Francesa. 


\section{LA DERNIERE MERVEILLE DÜ SIECLE

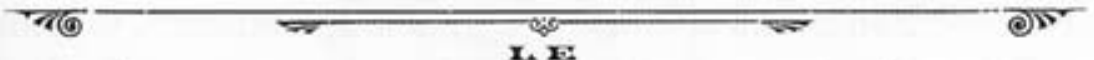
“ CINÉMATO=GRAMO=THÉATRE"
POUR PROJECTIONS PARLANTES \\ ot \\ CINÉMATOGRAPHE relië par le- nouvel Appareil de Synchronisme

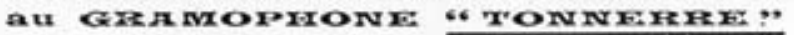 \\ atavictis ad resen and}
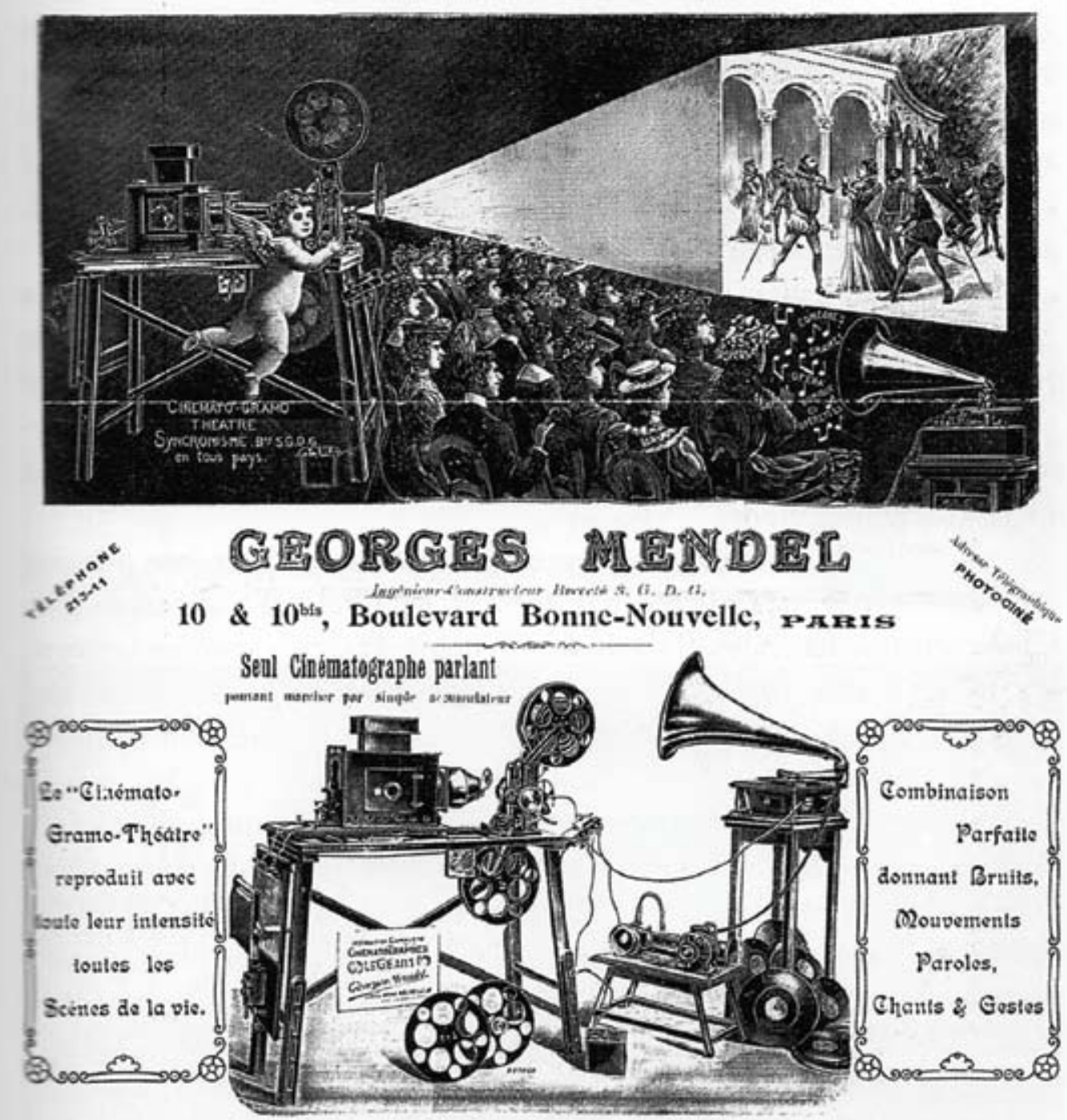

FIGURA 12 - Anúncio publicitário do projetor "Cinémato-Gramo-Théatre", projetor bifuncional que era associado a um gramofone e destinado à sincronização sonora de filmes cantantes. Fabricante: Georges Mendel, 1912. Coleção privada. Reproduzido em: PISANO, G.; POZNER, V. (Org.) Le muet a la parole. Cinéma et performances à l'aube du XX siècle. Paris: AFRHC, 2005, p. 43. Cortesia Laurent Mannoni. 
renovaram e reformularam um conjunto de práticas de entretenimento já tradicionais e familiares ao público, propondo "um novo lance num antigo jogo de enganar os sentidos e dos misteriosos prazeres que isto evocava"66, que no entanto teria os seus próprios desdobramentos.

Também em Porto Alegre, a introdução do cinematógrafo ocorreu num contexto em que uma longa tradição de espetáculos de projeções ópticas já havia assegurado a tal entretenimento uma organização, um espaço e uma importância cultural consideráveis. Sair de casa para ir a um espaço público e com acesso pago para assistir a espetáculos que incluíam as projeções luminosas era uma prática social e cultural familiar tão regular quanto o permitido pelo caráter episódico e temporário da sua exibição. Tal aspecto seria determinante na qualidade da apropriação dos porto-alegrenses às projeções cinematográficas e na afirmação do cinema como novo gênero de espetáculo e novo espaço de congregação social na esfera pública.

O lançamento do cinematógrafo no mercado do entretenimento mundial não determinou, no entanto, uma única e definitiva forma de sua exploração comercial. Na primeira década do século XX, não se ia a um espetáculo de projeções para assistir a um único filme, contando uma única história com começo, meio e fim, mas para apreciar uma série de atrações de natureza distinta, fossem filmes e vistas fixas, quando as projeções eram a atração exclusiva, fossem números de outros gêneros, quando os programas eram mistos. A grande maioria dos primeiros filmes não contava histórias, limitando-se a registrar cenas de trabalho ou domésticas, eventos públicos e espetáculos familiares aos contemporâneos. Eles mostravam alguma prática cotidiana, uma situação e/ou ação num curto espaço de tempo; não tinham compromisso com a narrativa, nem com a moralidade, respondendo a um projeto e uma lógica diversos daqueles que seriam estabelecidos a partir de 1906-1907, quando teve início a narrativização do cinema ${ }^{67}$.

Tal característica fazia com que cada filme fosse percebido como uma atração, de certa forma autônoma, o que facilitava a organização dos programas a partir da associação das projeções com atrações de outros gêneros de diversões ou em arranjos de vistas animadas e fixas. Mesmo um programa reunindo exclusivamente filmes podia ser apreciado como um pequeno espetáculo de variedades. Essa condição estimulou a incorporação das vistas fixas como imagens alternativas nos espetáculos exclusivamente de projeções, promovidos pelos exibidores cinematográficos itinerantes. A prática foi facilitada pelo caráter descontínuo e fragmentado da exibição cinematográfica durante sua primeira década de atividade em Porto Alegre. $\bigcirc$ conjunto desses aspectos, contudo, não foi peculiar ao cinematógrafo ou instituído por ele, sendo comum ao contexto espetacular e cultural do seu surgimento.

Entre 1897 e 1908, numerosos e distintos exibidores itinerantes independentes, assim como companhias artísticas de diferentes gêneros de diversões (circo, teatro, prestidigitação e variedades), realizaram projeções cinematográficas em Porto Alegre. Apresentando-se por temporada, conforme a dinâmica do setor de entretenimento da época, ocuparam desde os centros de diversões já existentes até espaços especializados em projeções, abertos para
66. Cf. Tom Gunning (1996, p. 38).

67. Ver Flávia Cesarino Costa (1995). 
68. A partir de 1903 , as projeções cinematográficas passaram a animar a popular e antiga festa religiosa do Divino Espírito Santo, realizada na praça Marechal Deodoro a cada início de inverno. A partir de 1907 , o cinematógrafo já incrementava as atrações noturnas da Festa da República, comemorativas ao 15 de Novembro. A partir de 1909, animou a Festa da Uva local. funcionar temporariamente. As projeções foram oferecidas ao público tanto como atrações exclusivas quanto complementares dos programas, que não obedeceram a um modo único de organização. Nesse sentido, deu-se continuidade a certos usos e práticas espetaculares já experimentados no século anterior, tendo sido simultaneamente estabelecidos novos padrões de exibição.

A heterogeneidade da oferta também facultou um acesso diversificado às imagens e possibilitou uma grande variedade nas formas de sua apropriação pelos espectadores. Uma das modalidades de exibição empreendidas localmente deu continuidade ao modelo, introduzido pelos pioneiros Paola e Renouleau, de espetáculos exclusivamente de projeções apresentados em salas especializadas temporárias. Neste caso, as vistas eram projetadas em sessões noturnas sucessivas, de aproximadamente 30 minutos de duração. Outra modalidade, também autônoma, consistia na apresentação das projeções como atrações exclusivas de espetáculos realizados nos centros de diversões locais, sobretudo nos teatros, o que ocorreu a partir de 1901.

A institucionalização dos teatros como espaços apropriados também aos espetáculos exclusivamente de projeções estava relacionada a um esforço de afirmação do cinema como gênero espetacular, o que se daria igualmente pela incorporação de práticas peculiares à organização teatral. Em resultado, os espetáculos ganharam longa duração e intervalos, sendo realizados "por função", isto é, uma vez por dia, à noite. Eles também podiam ocorrer aos domingos à tarde, como matinê. Seus programas eram organizados em torno da exibição dos dois gêneros de imagens, as vistas animadas e fixas, e contavam com eventuais intervenções sonoras e possivelmente orais.

Acessíveis por ingressos de preços diferenciados, custavam mais caro do que os espetáculos realizados "por sessões", tanto pela sua duração estendida quanto pela sua variedade e comodidade. Neste modo de exibição foram estabelecidos padrões de organização interna e externa do espetáculo, os quais foram seguidos, em seus princípios gerais, pela maioria dos exibidores ao longo dos anos. Também foi aquele que abrigou as mais diversificadas iniciativas promocionais, como as funções de gala, da moda e as comemorativas a datas históricas, além de reduções nos preços dos ingressos e meia-entrada infantil.

Uma terceira modalidade de exibição caracterizou-se pela manutenção das projeções como atrações complementares e finais de espetáculos mistos de outros gêneros de diversões, tal qual aconteceu na tradição lanternista. A exibição das vistas animadas e fixas nos espetáculos das companhias de variedades caracterizou a associação mais frequente, não somente por terem estas se tornado mais numerosas no período, mas por comungarem com o cinematógrafo os mesmos interesses e expectativas de atualidade e diversidade que caracterizaram tanto a oferta cultural quanto a demanda do público da época.

Essas distintas formas de incorporação e apresentação das projeções foram contemporâneas e alternaram-se, conjugando-se ainda a outras práticas menos comuns, mas significativas, como a realização de projeções ao ar livre em festas populares religiosas, políticas e agrícolas ${ }^{68}$. Enquanto a terceira modalidade sofreu um claro declínio, as duas primeiras transformaram-se, no sentido da 
especialização. A incorporação das vistas fixas como um gênero de imagens alternativo e complementar, não necessariamente secundário, foi operada em todos os modos de exibição referidos, sendo mais evidente e representativa, porém, nos espetáculos exclusivamente de projeções realizados nos teatros.

A tradição lanternista na era do cinematógrafo (1897-1908)
69. Cf. Rick Altman (2005, p. 90).

A incorporação das vistas fixas aos espetáculos exclusivamente de projeções, promovidos pelos exibidores cinematográficos itinerantes, foi uma prática recorrente entre 1897 e 1907, sendo lícito reconhecer que ela contribuiu significativamente para a autonomização do cinema como novo gênero espetacular, na medida em que permitiv estender e diversificar os programas, dando condições para sua especialização.

A iniciativa pode ser explicada pela conjugação de diferentes fatores, de ordem técnica, prática e sensível. $\bigcirc$ primeiro aspecto diz respeito à bifuncionalidade dos aparelhos projetores, característica originária da fabricação e não da adaptação do dispositivo pelos exibidores, aspecto que foi apropriado, e empregado como uma possibilidade de incremento dos espetáculos pela via da diversidade, tão valorizada na época.

Nos Estados Unidos, segundo Rick Altman ${ }^{69}$, essa dupla função respondia à necessidade de dar continuidade ao espetáculo e camuflar a demora da troca de filmes. Mas tal interpretação não parece se adequar ao contexto local, onde os programas dos espetáculos eram organizados de modo a manter separados os conjuntos de vistas pela sua natureza tipológica, fixa ou animada, chegando-se mesmo a intercalar cada troca de conjunto com um intervalo ou uma outra atração, musical, por exemplo. No caso de Porto Alegre, onde raros exibidores empregaram dois aparelhos distintos para projetar as vistas fixas e os filmes, o que se depreende dos comentários da imprensa é que as primeiras não foram oferecidas pelos exibidores ou percebidas pelo público como uma deficiência ou uma casualidade. Eram apreciadas como um atrativo extra dos programas, que conferia maior liberdade de opção em relação ao gênero e à qualidade formal e estética das imagens projetadas, enriquecendo o espetáculo dos pontos de vista perceptivo e cognitivo. Tanto as vistas fixas quanto as animadas foram muito aplaudidas pelos espectadores locais, sendo ambas objeto de pedidos de bis, isto é, de reprise.

Na verdade, houve reclamações contra a demora da troca de filmes durante as projeções em Porto Alegre, mas isso no início do século, num contexto em que os exibidores ainda atuavam sozinhos e concentravam diferentes funções. Tais críticas recrudesceram na medida em que esses se organizaram em pequenas empresas e passaram a empregar técnicos e auxiliares. Assim, a continuidade da exibição das vistas fixas nos espetáculos exclusivamente de projeções parece ter atendido sobretudo às expectativas e interesses dos contemporâneos, que apreciavam ambos os gêneros de imagens. 
Essa continuidade, no entanto, foi relativa, pois os modos de exibição das vistas fixas no novo cenário evidenciam transformações das práticas anteriores. A concorrência com as imagens cinematográficas, e a necessidade de atender à demanda pública pela atualização, estimularam os exibidores a racionalizarem e redefinirem os seus acervos de vistas fixas, especializando-os e constituindo coleções temáticas (turismo, arte, história). As vistas também foram diversificadas e renovadas do ponto de vista formal, empregando-se as diferentes tipologias de imagens como elementos distintivos dos programas (placas de vidro pintadas; fotográficas, em P\&B e em cores; estereoscópicas).

A exibição conjunta das vistas fixas e animadas possibilitaria um diálogo crescente entre as imagens e os acontecimentos cotidianos, outra demanda cultural da época. Atentos à importância da identificação temática entre espectadores e imagens projetadas e às implicações desse envolvimento para o sucesso (econômico) de suas temporadas, os exibidores procuraram apresentar imagens que dessem conta de tal interesse, independente de sua natureza (filmes, fotografias, ilustrações). As diferentes perspectivas de observação e representação da realidade, materializadas nas imagens, permitiriam um crescente cruzamento das informações visuais entre si, e dessas com aquelas textuais, proporcionando uma abordagem multifacetada dos eventos noticiados na imprensa escrita, capaz de ampliar o horizonte informacional dos espectadores e complexificar a sua experiência sensível.

Pode-se perceber essa prática como expressão de um momento de transição, num processo de substituição gradual de uma tradição visual, lanternista, por outra, cinematográfica, esta representando um novo estágio no processo de apropriação visual do mundo pelo homem. $\bigcirc$ cinema procurou respeitar e suprir as expectativas vigentes, ao mesmo tempo em que estimulava sua transformação, abrindo um novo horizonte de possibilidades de entretenimento e conhecimento.

Se não foi o cinema que forneceu os primeiros passaportes para que as pessoas pudessem "viajar sem sair do lugar", as suas imagens viriam incrementar a prática de ver o Egito sem deixar Porto Alegre, já proporcionada pelas vistas fixas. $\bigcirc$ cinema enriqueceria essa apropriação do ponto de vista perceptivo, acrescentando à memória visual dos porto-alegrenses, já habitada por imagens imóveis de monumentos arquitetônicos e obras de arte, cenas cotidianas animadas da vida egípcia, por exemplo.

Nos espetáculos de projeções que realizaram na cidade, o uso mais frequente e instigante que os exibidores cinematográficos itinerantes conferiram às vistas fixas concentrou-se sobre um determinado conjunto temático: o dos retratos de personalidades históricas e políticas. Tais vistas costumavam ser exibidas em funções de gala e comemorativas a datas históricas, sendo a sua projeção comumente acompanhada pela execução ao vivo de hinos cívicos. A formalidade da ocasião era intensificada pela presença real de autoridades e representantes das classes dirigentes locais entre o público, alguns dos quais eram, por vezes, homenageados nas projeções. Esse conjunto de vistas e práticas espetaculares estimulou manifestações as mais efusivas dos espectadores, que se dividiam e 
expressavam suas tendências políticas ${ }^{70}$. A própria imprensa, em seus comentários, revelava qual era a "torcida" com a qual se alinhava.

$\bigcirc$ primeiro a promover espetáculos do gênero foi o prestidigitador Faure Nicolay, na temporada que realizou no Theatro São Pedro em 1897. Os seus programas de variedades eram encerrados por projeções que incluíam vistas fixas com retratos de políticos nacionais. Dentre elas, destacou-se a vista do marechal Floriano Peixoto, que, projetada, provocou "uma verdadeira tempestade de aplausos, vivas e aclamações"71 entre o público. Essa mesma vista foi exibida pelo prestidigitador em São Carlos, interior de São Paulo, em outubro de 1898, provocando igualmente fervorosas manifestações da plateia, de apoio, e de oposição ${ }^{72}$.

No ano seguinte, durante a temporada da Companhia de Variedades Dramáticas de Germano Alves, no mesmo teatro, as vistas fixas dessa temática provocaram novas manifestações políticas dos espectadores. Em tais espetáculos, especializados em representações cênicas, as projeções concentravam importância secundária, sendo exibidas como atração alternativa entre duas comédias. Cada projeção reunia seis "quadros" ou filmes, sendo que, a cada troca, o teatro era "iluminado à luz elétrica", o que evidencia o caráter descontínuo das projeções e do espetáculo, em que a própria iluminação era destacada como uma atração extra.

público aplaudia os filmes, que eram substituídos a cada função, e pedia a reprise de alguns títulos. Rapidamente, porém, passou a reclamar da brevidade das projeções e do reduzido número de vistas exibidas a cada função. A fim de contornar o problema, o exibidor solicitou ao fotógrafo local Virgílio Calegari que the cedesse ou preparasse vistas fixas para projeção, no que foi atendido, vindo a projetar retratos de políticos como Júlio de Castilhos, Campos Salles, Floriano Peixoto e Prudente de Morais ${ }^{73}$. O caso demonstra que os fotógrafos locais tinham condições de produzir placas de vistas fixas para projeção ${ }^{74}$, e que o exibidor empregava um aparelho bifuncional.

Outra iniciativa promocional de Germano Alves foi o espetáculo de gala organizado para projetar as novas imagens. Este, que homenageou Tiradentes, foi aberto com a execução ao vivo do Hino Nacional por uma orquestra, prosseguindo com a representação de uma comédia e, a seguir, as projeções. Foram exibidas vistas animadas e fixas, sendo que uma banda da Brigada Militar executou novamente o Hino Nacional durante a projeção das vistas fixas com os "retratos dos sr. Castilho e do finado sr. Floriano"75. As manifestações públicas desencadeadas pela apresentação das figuras políticas, neste espetáculo e no seguinte, foram descritas pelas folhas locais, que também acabaram tomando partido:

a castilhice presente rompeu em impropérios e brados violentos ao aparecerem no cinematógrafo os retratos dos ilustres brasileiros e beneméritos republicanos drs. Campos Salles e Prudente de Morais [...] Felizmente o auditório não se compunha apenas de devotos do... fim do mês e, por isso, os dois respeitáveis patriotas receberam saudações que abafaram a vozeria desse grupo de desordeiros ${ }^{76}$.
70. Esta característica, observada em Porto Alegre, deve ter sido um traço comum também a outras cidades do país na mesma época, apesar das raras referências a respeito nos estudos sobre a história do cinema no Brasil. Afinal, diversas regiões $\mathrm{e}$ localidades foram percorridas pelos mesmos exibidores, os quais empregaram os mesmos aparelhos e exibiram os mesmos acervos de imagens, executando basicamente as mesmas práticas espetaculares. A exceção fica com os pesquisadores Vicente de Paula Araújo (1976; 1981) e Ary B. Leite (1995), que identificaram tais práticas em seus estudos.

71. Cf. A Federação, Porto Alegre, ano 14 , n. 168 , p. 2 , 26 jul. 1897.

72. Ver José Inácio de Melo Souza (2005).

73. Ver Antônio Jesus Pfeil (1999).

74. Aparelhos e acessórios do gênero eram comercializados no meio local. Tanto as casas especializadas em materiais ópticos quanto os estúdios fotográficos podiam dispor de profissionais especializados, capazes de confeccionar placas de vidro para lanterna mágica, sobretudo com imagens fotográficas. De resto, os fotógrafos ainda usavam suportes de vidro para os negativos e empregavam pintores para a pintura ou retoque de retratos fotográficos.

75. Cf. A República, Porto Alegre, ano 4, n. 86, p. 2, 22 abr. 1898 .

76. Idem, p. 1 
77. Cf. A República, Porto Alegre, ano 4, n. 88, p. 2, 25 abr. 1898.

78. Cf. A Federação, Porto Alegre, ano 15 , n. 93 , p. 2 , 25 abr. 1898.

79. Ver Roger Chartier (1991).
Neste caso, o jornal A Reforma critica as vaias recebidas pela figuras citadas porque era um órgão do Partido Republicano Liberal e, assim, opositor político dos partidários do Partido Republicano Rio-Grandense, identificados como "castilhice", em referência ao seu chefe maior, Júlio de Castilhos. Alguns dias depois, a companhia apresentou o seu espetáculo de despedida, quando reprisou as vistas fixas que haviam causado rebuliço na plateia no espetáculo de gala, reconhecendo o sucesso da iniciativa e colocando-o novamente à prova. Não foi outro o resultado. Assim que apareceram na tela os retratos ampliados de Campos Salles e Prudente de Morais, nova manifestação irrompeu entre os presentes, mas desta vez os seus partidários cuidaram em encher o teatro, de modo que "uma ruidosa salva de palmas [...] abafou por completo os tolos dichotos do grupinho castilhista"77. A folha representante deste "grupinho", a Federação, não deu o braço a torcer e relatou o contrário: "Ontem, com a plateia a transbordar [...] o retrato do Beriba levou um trote colossal"78. "Beriba" era o apelido com que os adversários políticos de Prudente de Morais costumavam depreciá-lo.

Como se pode perceber, foram as vistas fixas que acabaram rompendo com a apatia reinante sobre as projeções e restaurando o seu interesse junto ao público, via identificação temática. Sem dúvida, os perspicazes exibidores, ao organizarem tais programas e selecionarem tais temáticas, já alimentavam expectativas de maior envolvimento dos espectadores. $\bigcirc$ uso político e afetivo que fizeram de certas imagens fundamentava-se no reconhecimento dos valores e interesses dos espectadores. As iniciativas empreendidas no sentido de thes dar expressão visual contribuiriam para o estabelecimento de uma comunicação mais cúmplice entre exibidores e espectadores, conferindo um significado extra aos espetáculos e chamando a atenção para a importância desses eventos como dinamizadores das experiências e práticas sociais ${ }^{79}$.

$\bigcirc$ ano de 1901 seria especialmente rico neste sentido, em função da proliferação dos espetáculos de projeções na cidade. No período, numerosos exibidores cinematográficos deslocaram-se até Porto Alegre, em função da Exposição Estadual de 1901. Promovido pelo Governo do Estado como vitrine do progresso agroindustrial gaúcho, o evento atraiu à capital um grande contingente de visitantes, vindo de diferentes localidades do interior, e concentrou, assim, um potencial público também para as projeções. As sucessivas e variadas temporadas do gênero acabaram ampliando a experiência espectatorial do público e permitindo o estabelecimento de padrões de referência para a comparação e avaliação das ofertas de futuros exibidores. A partir de então, a qualidade técnica de suas projeções e a atualidade e diversidade de seus acervos de vistas seriam submetidos a um maior grau de exigência.

Foi a partir deste ano, igualmente, que os teatros e outros centros de diversões porto-alegrenses passaram a sediar espetáculos exclusivamente de projeções e predominantemente cinematográficos. José Barrucci inaugurou a nova modalidade de exibição, ocupando, de forma inusitada, pela primeira e única vez até 1909, o salão dos bilhares de um café, o Guarany (rua dos Andradas). Barrucci já era conhecido localmente, em função do grande sucesso que havia feito na cidade no ano anterior com o seu "Panorama Internacional", uma espécie 
de diversão óptica especializada na exibição de vistas fixas de temática turística.

Trabalhando diariamente à noite, este exibidor renovava os seus programas duas vezes por semana. Costumava exibir vistas fixas e animadas, nesta ordem, separadas por um intervalo. Projetava quatro filmes por vez, desde documentários de temática turística e atualidades mundiais, com destaque para as vistas da Exposição Universal realizada em Paris, em 1900, até filmes burlescos. Entre as vistas fixas apresentadas, constavam imagens, provavelmente fotográficas, de episódios militares e retratos de políticos nacionais e estrangeiros, sobressaindo o conjunto temático relativo à visita do presidente brasileiro Campos Salles à Argentina (1900). Além das vistas que registravam a recepção do presidente brasileiro pelo colega portenho, havia também imagens de pontos turísticos de Buenos Aires e do Rio de Janeiro ${ }^{80}$.

acontecimento representou a primeira viagem de um chefe de Estado brasileiro ao estrangeiro. Era uma visita de retribuição à iniciativa homônima e anterior do presidente argentino, que visitou o Brasil em agosto de 1899. Ambos os eventos diplomáticos ganharam detalhada cobertura na imprensa dos dois países, especialmente na revista ilustrada portenha Caras \& Caretas, que certamente também veiculou fotografias dos eventos ${ }^{81}$. As vistas fixas projetadas por Barrucci podem ter sido produzidas a partir desse mesmo grande conjunto de imagens documentais. Em maio, um filme registrando esta viagem do presidente brasileiro foi exibido em Porto Alegre por uma companhia de variedades portenha que se apresentou no Theatro São Pedro e na Exposição Estadual de 190182. Com a iniciativa, abriu-se aos espectadores a possibilidade de um diálogo não somente no nível dos conteúdos, mas também no dos aspectos formais e estéticos das representações.

Segundo relatos da imprensa posteriores às exibições, as vistas fixas foram tão apreciadas quanto as animadas, evidenciando o interesse do público pelas imagens em geral, independente do gênero. $\bigcirc$ caso particular do evento citado é significativo por demonstrar o novo potencial expressivo e cognitivo das tecnologias visuais. Se a imprensa diária ainda encontrava dificuldades técnicas para a reprodução de fotografias, as lanternas mágicas, os projetores cinematográficos e as primeiras revistas ilustradas vinham contribuir para viabilizar o crescente desejo do homem por uma apropriação visual dos acontecimentos contemporâneos, incrementando as possibilidades de construção de um conhecimento visual sobre o mundo ${ }^{83}$.

Logo após o encerramento da temporada de Barrucci no Café Guarany, tiveram início os espetáculos exclusivamente de projeções do argentino Henrique Sastre, no Theatro São Pedro, pela primeira vez ocupado para uma temporada do gênero. $\bigcirc$ exibidor também era conhecido localmente, mas por sua atuação como engenheiro (1899). Nessa que foi a primeira das quatro temporadas que empreendeu na cidade em 1901, Sastre deu funções diárias, noturnas, longas, cujos programas eram organizados em três partes intercaladas por intervalos. A cada parte correspondia um gênero distinto de imagens: vistas animadas em $P \& B$, "vistas fixas simples" e vistas fixas coloridas.
80. O programa especial dedicado ao evento tinha início com a exibição de 17 vistas fixas: 1. Couraçado Riachuelo, o desembarque em Buenos Aires; 2. Dr. Campos Salles e general Roca a bordo do Riachuelo; 3. Encontro do general Mitre e Campos Salles; 4. Carro presidencial; 5. Demonstração ao Dr. Campos Salles na grande Avenida de Maio; 6. Tribuna de Dárcena; 7. Passagem das tropas diante do Palácio do Governo; 8. Palácio Devoto; 9. Hipódromo Argentino; 10. Tribuna do Hipódromo Argentino; 11. Embarque da comitiva oficial; 12. Panorama do Porto do Rio de Janeiro com vista do Corcovado; 13. Avenida de Palmeira Real no Jardim Botânico do Rio; 14. Mercado do peixe; 15. Vista do porto; 16. Panorama da cidade do Rio com a vista do Pão de Açúcar; 17. Monumento de D. Pedro I. A segunda parte compreendia cinco vistas animadas de procedência europeia. Cf. $A$ Reforma, Porto Alegre, ano 34 , n. 25, p. 2, 20 fev. 1901. Essa folha não esclareceu a natureza das vistas. Foi a $\mathrm{Fe}$ deração quem o fez; cf. $\mathrm{Fe}$ deração, ano 18, n. 44, p. 2 , 20 fev. 1901.

81. Na viagem do presidente argentino ao Brasil, fazia parte da comitiva presidencial um repórter do periódico. A viagem do presidente brasileiro a Buenos Aires também foi tema de uma edição especial da revista, que circulava em Porto Alegre e cuja tiragem, deste número em particular, atingiu $\mathbf{5 2}$ mil exemplares. Cf. anúncio em $A$ Federação, p. 3, 4 mar. 1901

82. O filme foi anunciado na imprensa local como "Chegada do presidente Campos Salles a Buenos Aires a bordo do encouraçado Riachuelo". Segundo informações da Cinemateca Brasileira, São Paulo, foi realizado em 25 de outubro de 1900, em Buenos Aires, na Argentina, por Eugenio Py. Tratava-se de um curta-metragem de caráter 
documental, em P\&B, 35mm, que trazia cenas do "desembarque do Presidente Campos Sales do navio de guerra Riachuelo, na Darnesa Norte, em Buenos Aires, e da recepção encabeçada pelo General Julio Roca, Presidente da Argentina”.

83. Cf. Jacques Leenhardt (1997, p. 11).

84. Cf. A Federação, Porto Alegre, ano 18 , n. 49, p. 2, 26 fev. 1901.

85. Ibidem.

86. Cf. A Federação, Porto Alegre, ano 18 , n. 50 , p. 2 , 27 fev. 1901. A Companhia Dramática de Óperas e Operetas Bernini apresentou-se em Porto Alegre entre agosto e outubro de 1899 , no Theatro São Pedro, representando, entre outros títulos, a ópera Bohemia, de Puccini, quando foram certamente feitas as fotografias que deram origem à vista exibida por Sastre em suas projeções. Cf. A Reforma, Porto Alegre, ano 31 , n. 84, p. 1,17 abr. 1899; e A Federação, Porto Alegre, ano 16, n. 173, 31 jul. 1899.
No primeiro grupo, constavam filmes que tematizavam a vida campestre, movimentos de trens, vapores e respectivos passageiros, danças (Diretório e Serpentina) e exercícios militares. No segundo, retratos de políticos e personalidades locais e nacionais, provavelmente fotográficos e em P\&B, considerando-se a identificação e distinção da terceira coleção como sendo de vistas fixas coloridas. Esta última compreendia prováveis reproduções de pinturas. No início, meio e no final das funções, o exibidor também projetava vistas fixas com anúncios coloridos.

A sua estréia contou com a participação de uma orquestra, que executou - Hino Nacional durante a projeção das vistas fixas de figuras históricas, políticos e personalidades. Entre as vistas "fixas simples" projetadas, figuraram "retratos de alguns homens conhecidos nesta cidade, como sejam o nosso ilustre amigo e chefe dr. Júlio de Castilhos, dr. Presidente do Estado, dr. Montaury, Henrique Duplan, etc." ${ }^{84}$. Já as vistas "fixas coloridas" causaram forte impressão no representante da Federação. Ao descrever o que havia visto, o jornalista destacou a textura e os tons dos tecidos de certas composições, percebidos em função da qualidade técnica da projeção e das placas, concluindo que a "ilusão" teria sido tão "completa" a ponto de provocar "vontade de apalpar" 85 .

As vistas fixas de personalidades foram reprisadas pelo exibidor na primeira sessão pública, provocando novos comentários e trazendo novas informações sobre os seus conteúdos. Assim, soube-se que também ganharam grande ampliação os retratos de Campos Salles, presidente da República, marechal Floriano, major Cherubim Costa, chefe de polícia, "maestro Araújo Vianna, dr. Pinto da Rocha e fotógrafo Calegari, bem como um quadro representando em conjunto a Estudantina Porto-Alegrense e a cena final do último ato da Bohème pela companhia Bernini"86.

A sua temática não deixa dúvidas acerca das relações que Henrique Sastre já estabelecera na cidade e das que ainda pretendia promover com alguns de seus mais ilustres cidadãos. Era mais um exibidor a reconhecer a importância da representação de conteúdos locais, familiares aos espectadores, para o incremento de seus espetáculos e sua valorização junto ao público. A iniciativa pode ter sido facilitada pelo seu histórico pessoal, tendo vivido em Porto Alegre como viveu. Empregando uma tela gigante, um projetor bifuncional e fonte de luz elétrica, Sastre foi elogiado pela qualidade técnica dos seus espetáculos, fazendo enorme sucesso de público, a ponto de ser denunciado à polícia devido à venda abusiva de ingressos e superlotação do teatro.

Sastre e Barrucci realizaram projeções na Exposição Estadual de 1901 após as temporadas acima referidas, exibindo basicamente os mesmos acervos de vistas. Dois outros exibidores os sucederam na mesma função, tendo ambos apresentado vistas animadas e fixas. O primeiro, não-identificado, atualizou seus programas diariamente, apresentando filmes cômicos e documentários de guerra, assim como vistas fixas turísticas do Egito e de Santa Catarina, provavelmente fotográficas. Já a "Companhia de Reais Novidades", uma companhia de variedades portenha, especializada em números de grande impacto visual, entre eles a dança Serpentina, alternou as projeções de vistas e tais atrações. 
seu diferencial foi ter distribuído as projeções em dois momentos distintos do programa e não apenas ao final, propondo associações cujo resultado era uma composição visual dinâmica, que impressionava pela beleza. Dessa forma, a companhia revelou uma percepção mais aguçada dos usos das imagens e dos efeitos visuais que estes potencializam. Também no aspecto temático, o acervo de vistas animadas da companhia se distinguiu daqueles de outros exibidores, pelo predomínio de fantasias e cômicos coloridos, produzidos por Georges Méliès. Essa qualidade contribuiu para o diálogo entre os filmes, as danças e os demais números ginásticos e musicais que apresentou, intensificando o caráter onírico e lúdico dos espetáculos e evidenciando a ênfase no entretenimento.

Sua coleção também continha filmes de atualidades (documentais) e vistas fixas, com os tradicionais retratos de personalidades políticas, projetados já no espetáculo inaugural e com evidente intuito promocional. Na ocasião, foi exibido um conjunto temático denominado "Passagem dos personagens mais notáveis do mundo com suas respectivas bandeiras"87, com "retratos do presidente da República, dr. Campos Salles, e de vários presidentes da República, acompanhados dos respectivos escudos e cores nacionais" 88 . Durante a sua projeção, uma orquestra tocou os hinos das nações representadas, acentuando, com o caráter oficial das composições, a respeitabilidade do evento, já evocada na temática das vistas.

Em 1902, não houve projeções cinematográficas em Porto Alegre e nem projeções de lanterna. Em 1903, porém, José Barrucci voltaria à cidade para se exibir sucessivamente no Theatro-Parque (inaugurado em 1901), no Theatro São Pedro e na Festa do Divino, além de realizar projeções esporádicas na cidade vizinha de São Leopoldo, facilmente acessível por ligação férrea. Em seus espetáculos, projetou vistas animadas, na maioria já conhecidas, e também vistas fixas, prometendo programas inéditos a cada função, o que, como os seus concorrentes congêneres, não cumpriu.

Antônio Mecking, outro exibidor itinerante independente, ocupou o Theatro São Pedro em dezembro desse mesmo ano e ali exibiu vistas fixas e animadas. Logo após, abriu uma sala especializada de projeções na rua dos Andradas, onde deu continuidade à sua temporada. O maior destaque, porém, coube à "Imperial Companhia Japonesa Kudara", que se apresentou no Theatro-Parque, um centro de diversões ao ar livre, em pleno inverno. Embora tenha oferecido as projeções como atrações complementares de espetáculos variados, em que predominavam números ginásticos e circenses, a grande qualidade técnica e temática das vistas projetadas marcou aqueles que as assistiram. Em seu acervo, constavam filmes inéditos e coloridos, produzidos por Georges Méliès, como Viagem à Lua, Ali Babá e os 40 ladrões e Cinderela, além de vistas fixas em P\&B e coloridas.

Diferentemente dos exibidores anteriores, a companhia divulgou a utilização de dois aparelhos projetores distintos para a exibição de cada gênero de imagens. Um deles foi uma lanterna mágica aperfeiçoada, denominada "projetor elétrico L'Aester", que exibia as vistas fixas, sendo essas divididas entre retratos de personalidades políticas nacionais e estrangeiras, provavelmente em $P \& B$, e fotografias coloridas pelo processo do prof. Gabriel Lipmann. $\bigcirc$ outro
87. Cf. A Federação, Porto Alegre, ano 18, n. 109 , p. 2 , 9 maio 1901.

88. Cf. A Federação, Porto Alegre, ano 18, n. 111, p. 2, 11 maio 1901. 
89. Em Gazeta de Notícias, Rio de Janeiro, p. 2, 06 abr. 1903, apud Vicente de Paula Araújo (1976, p. 152)

90. A Federação, Porto Alegre, ano 20, n. 154, p. 2, 3 jul. 1903.

91. (Vicente de Paula ARAÚJO, 1981, p. 96)

92. Em Gazeta de Notícias, Rio de Janeiro, p. 2, 9 abr. 1903, apud Vicente de Paula Araújo (1976, p. 152).

93. Cf. A Federação, Porto Alegre, ano 21, n. 35, p. 2, 12 fev. 1904

94. Cf. O Independente, Porto Alegre, ano 4, n. 230, p. 2 , 25 fev. 1904

95. José Filippi, cujo nome completo era Vittorio Calcina Giuseppe Filippi, fez parte da primeira geração de operadores associados à Societé Lumière na Itália; $\mathrm{cf}$. Aldo Bernardini (1985, p. 69). Ele esteve entre os primeiros exibidores e cinegrafistas itinerantes que percorreram os diferentes países da Europa apresentando o cinematógrafo e suas fotografias animadas e simultaneamente produzindo filmes que eram incorporados ao seu repertório. A sua trajetória brasileira teve início em 1902 pela região norte aparelho era um projetor cinematográfico denominado Bioscope Captotricon de Farragut, que exibia os filmes ${ }^{89}$.

Em uma de suas funções, que teve o programa descrito em comentários posteriores, foram projetados "os retratos do presidente Rodrigues Alves, do imperador Guilherme, do rei Victor Emmanuel e de Santos Dumont, o ilustre aeronauta brasileiro"90. Trata-se das mesmas vistas fixas exibidas pela companhia em temporadas anteriores, no Rio de Janeiro e em São Paulo. Segundo um anúncio veiculado na imprensa paulista, também constavam no seu acervo vistas com retratos de D. Carlos, rei de Portugal, e do brasileiro coronel Plácido de Castro91. Após a exibição das vistas em P\&B, eram projetadas as vistas fixas fotográficas e coloridas, em número de dez, consideradas pelos cariocas como "belíssimas e de extraordinária nitidez" ${ }^{\prime \prime 2}$.

Em 1904, as projeções de vistas fixas e animadas associadas foram realizadas em diferentes locais e em espetáculos de distintos gêneros: uma das atrações de um circo estabelecido temporariamente na praça Gen. Osório; e, ainda, dos espetáculos de variedades realizados pela Companhia Eduardo Von Schultz no Theatro Polytheama (1 898). Também foram apresentadas no Theatro-Parque, por W. $H$. Westighouse, um exibidor autônomo, contratado por aquele centro de diversões para exibir as projeções, ora como atração complementar, ora exclusiva.

No acervo de vistas animadas deste último constavam filmes sobre acidentes, incêndios, salvamentos e crimes, provocando sensação entre os espectadores. No que respeita às vistas fixas, havia retratos de Borges de Medeiros, presidente do Estado, e do "inesquecível estadista e glorioso chefe republicano rio-grandense dr. Júlio de Castilhos" ${ }^{193}$. Por ocasião das funções especiais e festivas de Carnaval ali promovidas, e que contaram com a presença de duas sociedades carnavalescas locais e seus respectivos carros alegóricos, foram exibidas vistas fixas dessa mesma temática, diretamente relacionadas ao público que animava o local na ocasião, visto terem sido projetados o "retrato da popular e já falecida 'Bacalhau com ovo', do tio Pedro, edifício onde funciona os Pierrots, Piquete do comando do distrito e outras"94.

Tal seleção de imagens, registrando manifestações culturais locais, algumas das quais já extintas e relegadas à memória, é mais um exemplo dos esforços dos exibidores em mostrar-se integrados à realidade dos espectadores, exibindo imagens com as quais eles pudessem identificar-se. A prática atingiria o seu ápice no segundo semestre desse mesmo ano, com a filmagem e projeção de acontecimentos locais pelo italiano José Filippi. A temporada deste exibidor na cidade estendeu-se a dois teatros diferentes, o São Pedro e o Polytheama. Os seus espetáculos, exclusivamente de projeções, foram organizados como funções, tendo sido empregado um projetor bifuncional e fonte de luz elétrica, e exibidas vistas animadas e fixas. Filippi era também um importante cinegrafista e foi o primeiro a filmar eventos locais e a projetá-los na cidade ${ }^{95}$.

Seus programas foram organizados em três partes, separadas por intervalos. Cada uma delas foi reservada a uma categoria particular de imagens. A primeira era dedicada exclusivamente à projeção de vistas fixas, constando de três conjuntos temáticos: de arte (acervos de museus europeus), de cidades (interesse 
turístico) e de retratos de personalidades políticas. As vistas das duas primeiras "coleções" eram coloridas, assim como alguns dos filmes de seu repertório. A segunda e terceira partes eram dedicadas à exibição de vistas animadas, começando com filmes com efeitos sonoros (sonoplastia), ou sobre eventos locais, e terminando com filmes estrangeiros silenciosos, em que a produção francesa predominava.

Com tal organização, o exibidor demonstrava simultaneamente especialização (em espetáculos exclusivamente de projeções) e variedade (de gêneros de imagens para projeção, fixas e animadas, P\&B e em cores, silenciosas e com efeitos sonoros, documentais e ficcionais, locais, nacionais e estrangeiras). Embora a distribuição proposta evidencie a importância maior das vistas animadas, que ocupavam 2/3 do programa, Filippi concedeu às vistas fixas um valor renovado. Diferente de seus colegas exibidores, reservou-lhes um espaço definido e fixo nas projeções, limitando-se à exibição de conjuntos especializados de vistas, tanto do ponto de vista temático quanto formal, visto que provavelmente eram fotográficas. Dessa forma, ele representou a ruptura e a continuidade em relação à herança anterior, reconhecendo, na prática, o parentesco, e a dívida, do cinematógrafo para com a lanterna mágica, suas imagens, modos de exibição, público e respectivas expectativas, mas conferiu-thes novos significados a partir da exploração atualizada de ambos os gêneros que propôs.

No que respeita aos conjuntos temáticos de vistas fixas artísticas e turísticas, concentravam-se majoritariamente em referentes italianos. Sob o título Visões da Arte, constavam reproduções de obras de arte de museus europeus, entre os quais o do Vaticano. Placas como a representada pela figura 13 costumavam integrar coleções de imagens cuja projeção permitia uma espécie de visita imaginária às instituições estrangeiras e com grande economia, pois se gastava apenas o valor do ingresso para a exibição.Também foram exibidos conjuntos de vistas de monumentos e pontos turísticos de cidades italianas, como Veneza, Roma, Vaticano, Nápoles, Herculano e Pompeia. Segundo a imprensa, em função de seu "belíssimo efeito", tais panoramas coloridos foram muito apreciados e aplaudidos pelo público. Sobre a coleção de vistas romanas, informou-se que compreendia imagens representando "monumentos, quadros históricos, trabalhos de artistas célebres" como "Del Sarto, Guido Reni, Domenichino, Loti, Head Virginia Lebrun, Tisiano, Balloni, Murillo, Barabino, Guercino, Leonardo da Vinci e outros", além de "retratos em tamanho natural do malogrado rei Umberto I, dos atuais soberanos italianos e outros"96. $\bigcirc$ conjunto intitulado As portas de Roma trazia, entre outras, imagens "da Roma antiga, arco dos Imperadores, Fórum, Coliseu, etc." 97 , que "agradaram muito" mesmo quando repetidas, "quer pelo histórico, quer pela brilhante combinação de luzes que lhes empresta realce encantador" ${ }^{\prime \prime}$.

A especificidade temática dessas vistas e o seu forte teor informativo, somados ao provável ineditismo de muitas das imagens para boa parte do público, tornavam no mínimo interessante, senão imprescindível, a intervenção do exibidor, no sentido do acompanhamento oral da exibição. A prática foi muito comum e duradoura em diferentes países do mundo, tanto nos espetáculos de projeções de lanterna mágica quanto naqueles cinematográficos do período silencioso. Os
96. Cf. A Federação, Porto Alegre, ano 21, n. 180, p. 2, 5 ago. 1904

97. Cf. A Federação, Porto Alegre, ano 21, n. 191, p. 2, 18 ago. 1904.

98. Em Jornal do Comércio de 20 ago. 1904, apud Fábio Augusto Steyer (1998, p. 36). 


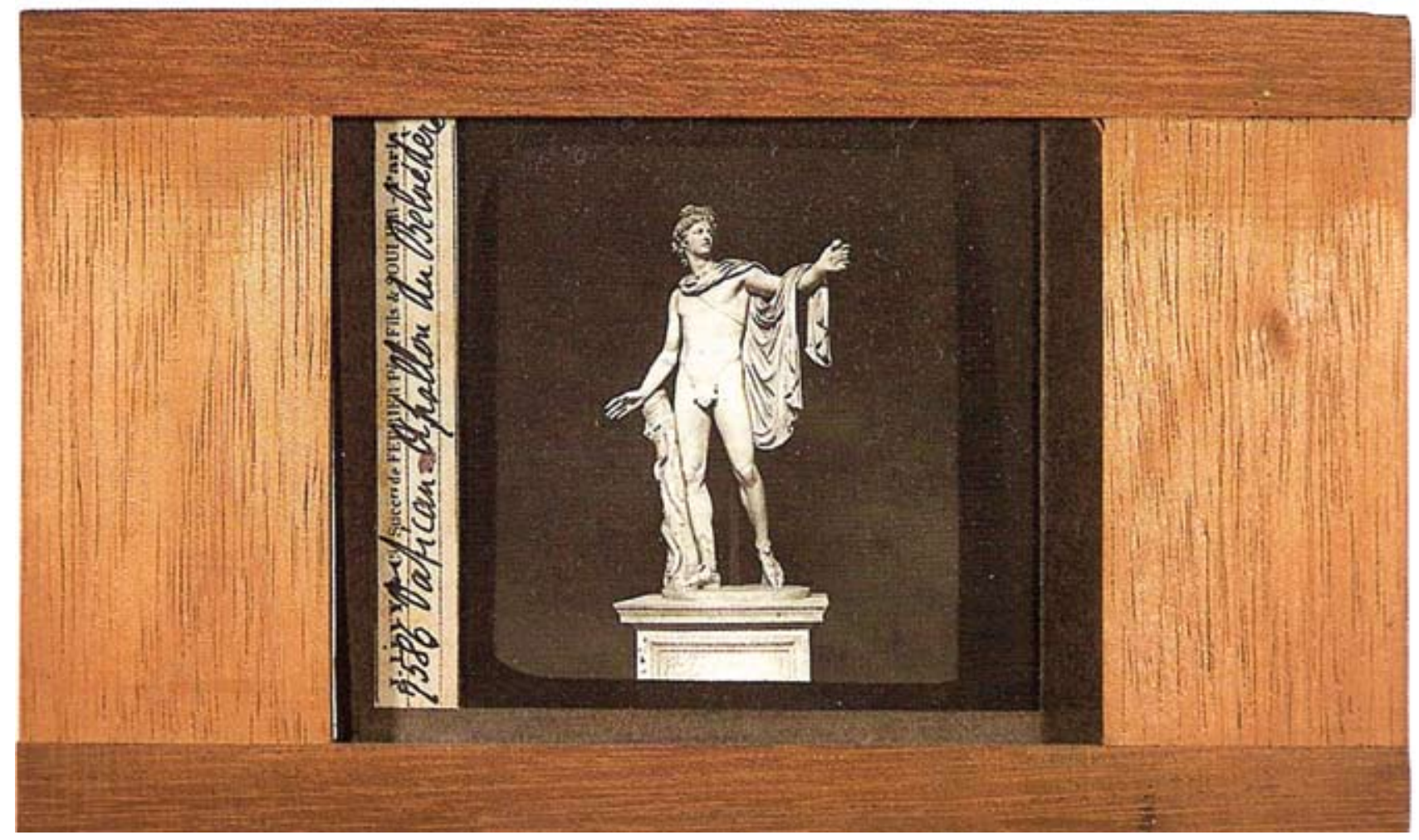

FIGURA 13 - Placa para lanterna mágica. Arte: Apolo de Belvedere. Fotografia P\&B sobre vidro. 10,7 x 17,8 cm. França, final séc. XIX. Acervo do Museu do Cinema da Filmoteca Espanhola, Madri. Reproduzida em: 50 años de la Filmoteca Española. El cine español en los años 50 [catálogo]. Madri: Sociedad Estatal de Commemoraciones Culturales, 2003, p. 1 15. Cortesia Filmoteca Espanhola.

99. Ver André Gaudreault e François Albera (2005).

100. Ver Max Nabarro (1997).

101. Cf. O Independente, Porto Alegre, ano 4, n. 286, p. 2,8 set. 1904 . "explicadores" dos filmes profissionalizaram-se em alguns países, chegando a disputar concursos entre a categoria, conforme ocorreu no Japão, Rússia e Canadá 99 . Na Holanda, esses profissionais inclusive se sindicalizaram ${ }^{100 .}$.

Quanto ao conjunto das vistas fixas de retratos de personalidades históricas e políticas, foi novamente aquele que se prestou aos usos promocionais mais evidentes. Nos espetáculos de Filippi, tais imagens eram projetadas segundo o mesmo objetivo e modo de exibição dos seus antecessores, ou seja, como atrações adicionais, destinadas a incrementar e dar formalidade a espetáculos especiais comemorativos a datas históricas, merecendo, da mesma forma, acompanhamento musical ao vivo, mas pontual.

A primeira função de gala promovida por Filippi homenageou a Independência do Brasil e teve lugar no Theatro São Pedro, contando com um programa especialmente organizado em torno dessa temática. Na parte inicial, reservada às vistas fixas, foram projetados "diversos retratos de brasileiros ilustres que se destacaram na guerra do Paraguai e os dos drs. Rodrigues Alves, Presidente da República, Júlio de Castilhos, Barão do Rio Branco, Borges de Medeiros e outros" 101 . Segundo A Federação, teriam sido projetados, simultaneamente à 
execução do Hino Nacional, retratos de todos os presidentes da República, desde a sua proclamação, e uma alegoria ao suplício de Tiradentes.

Na segunda parte do programa, em correspondência temática, figuraram "vistas de assuntos nacionais", "apanhadas em diversos pontos do Brasil, desde Manaus até esta capital", incluindo as "principais cidades do nosso Estado". Eram filmes provavelmente realizados pelo próprio Filippi ao longo de sua trajetória exibidora, desenhando assim um novo mapa do país construído pelo cinema e que incluía Porto Alegre. Inicialmente foram projetadas as vistas das cidades de outros estados. Após, foram exibidas novamente as vistas fixas com os retratos dos políticos estaduais ao som do Hino Nacional e só então foram apresentadas as "vistas desta capital, Rio Grande, Pelotas, Bagé e outras" 102. O público aplaudiu profusamente todas as vistas, inclusive as fixas.

A "função de despedida", com a qual Filippi encerrou sua temporada no São Pedro, incluiu no programa as mesmas "vistas nacionais", regionais e locais já exibidas, bem como os retratos de Borges de Medeiros e Júlio de Castilhos. Uma banda musical executou, provavelmente durante a projeção das vistas fixas, o Hino Rio-Grandense. O sucesso dessa função acabou estimulando o exibidor a permanecer na cidade e dar continuidade às suas exibições, mas desta vez no Theatro Polytheama. Ali, duas outras funções de gala foram realizadas, uma em homenagem à Revolução Farroupilha e a outra "de despedida".

Para a função comemorativa ao evento histórico estadual, Filippi novamente preparou um programa especial temático, cuja seleção de vistas contribuiu para salientar o caráter quase oficial do evento, estimulando e/ou enfatizando a presença de autoridades. Este compreendia vistas fixas e cinematográficas novas, respectivamente o conjunto $\bigcirc$ Rio Grande do Sul ilustrado - Retratos de homens ilustres rio-grandenses e A defesa da bandeira nacional, vista tirada no $2^{\circ}$ Batalhão da Brigada Militar ${ }^{103}$. Os espetáculos começaram com a projeção das vistas fixas, sendo exibido o retrato de Rodrigues Alves, presidente da República, ao som do Hino Nacional, ouvido de pé. Sucederam-se os retratos de Borges de Medeiros e Júlio de Castilhos, entre outros vultos da história política do Estado, projetados ao som do Hino Rio-Grandense, também ouvido de pé.

Os usos temáticos das imagens caracterizaram outros espetáculos comuns oferecidos por Filippi. Neles, o exibidor costumava reunir num mesmo programa registros de diferentes naturezas, desde vistas animadas e fixas até elementos sonoros, com a finalidade de dar ao espectador a oportunidade de cruzar abordagens, informações e sensações, estimulando uma apropriação mais complexa dos acontecimentos. Um exemplo foi uma função cujo programa compreendia "vistas cinematográficas da corte pontifícia de Leão XIII" (18781903)104, em que o papa aparecia "abençoando o povo", além de vistas, também animadas, da "chegada dos cardeais ao Vaticano e as de um passeio dado pelos jardins, também do Vaticano"105. Complementavam a seleção vistas fixas de monumentos e obras de arte de museus do Vaticano ${ }^{106}$.

Outro exemplo foi a função que reuniu "quadros fixos e cinematográficos da guerra russo-japonesa" (1904-1905). $\bigcirc$ conflito, então em curso, motivou a produção de uma extensa filmografia, apresentada por diferentes exibidores que
102. Cf. A Federação, Porto Alegre, ano 21, n. 209, p. 3 , 8 set. 1904 .

103. Cf. A Federação, Porto Alegre, ano 21, n. 218, p. 2, 19 set. 1904 . Os dados reunidos na imprensa indicam que esta vista também foi filmada por Filippi em Porto Alegre.

104. Cf. A Federação, Porto Alegre, ano 21 , n. 188 , p. 2 , 15 ago. 1904.

105. Cf. Correio do Povo, Porto Alegre, n. 228, p. 1, 17 ago. 1904 .

106. Cf. anúncio em Correio do Povo, Porto Alegre, p. 2, 15 ago. 1904. 
107. Cf. A Federação, Porto Alegre, ano 21, n. 182, p. 2, 8 ago. 1904 .

108. Ibidem

109. Ibidem.

110. Cf. A Federação, Porto Alegre, ano 23, n. 25, p. 2, 29 jan. 1906. visitaram a cidade no período. No espetáculo proposto por Filippi, foram projetados, além dos filmes tomados no campo de batalha, vistas fixas com "retratos dos personagens mais em evidência dos dois países empenhados na encarniçada pugna travada no Extremo-Oriente, principais navios de guerra, episódios de guerra, etc." ${ }^{107}$.

Segundo a imprensa, a reação dos espectadores a essas projeções foi efusiva: "os aplausos eram constantes, bem como os pedidos de bis aos quadros mais interessantes, que também davam lugar a manifestações de simpatia de espectadores partidários de ambos os lados combatentes" 108 . O envolvimento do público e suas manifestações de adesão e contrariedade foram, neste caso, intensificadas pela atualidade das imagens e pelo fato de o conflito ocupar diariamente as páginas dos jornais locais. Como se não bastasse, Filippi acionou o seu fonógrafo em um dos intervalos, fazendo-o tocar "escolhidos trechos de ópera e uma original canção japonesa, que agradou imenso"109. A escolha do repertório musical não deve ter sido gratuita, contribuindo para potencializar os efeitos das imagens e vice-versa.

Em 1905, os exibidores cinematográficos apostaram em diferentes usos de elementos sonoros para incrementar os seus espetáculos de projeções, privilegiando os filmes cantantes em detrimento das vistas fixas. A exibição destas voltou a ser referida em janeiro de 1906, na temporada de um exibidor nãoidentificado, que realizou projeções no Theatro-Parque. Também este fez uso de vistas fixas e animadas, de personalidades e temáticas históricas e políticas, entre outras, procurando apresentá-las em ocasiões e situações capazes de ressaltar a importância das imagens como veículos de informação sobre os acontecimentos cotidianos contemporâneos. Um exemplo foi o programa que reuniu imagens como o retrato do general argentino Bartolomeu Mitre, uma alegoria ao encouraçado nacional Aquibadan e uma vista do atentado que resultou na morte do grão-duque Sérgio, em São Petersburgo ${ }^{110}$.

A embarcação de guerra brasileira Aquibadan acabara de naufragar na baía de Jacuecanga, no Rio de Janeiro. $O$ desastre marítimo, ocorrido havia menos de 10 dias, fora provocado por um incêndio seguido de explosão. A morte de quase toda a tripulação provocou comoção nacional, levando o próprio TheatroParque a suspender os seus espetáculos por quatro dias, em sinal de luto. $\bigcirc$ falecimento do militar e ex-presidente da Argentina Bartolomeu Mitre (1821-1906) também era fato recente, tendo ocorrido em Buenos Aires em 19 de janeiro. Quanto ao grão-duque Serge Romanov (1 857-1905), havia sido assassinado há quase um ano, sendo por isso provável que a vista sobre este tema fosse cinematográfica, uma "atualidade reconstituída", enquanto as vistas anteriores eram fixas. Neste caso, observa-se que a seleção foi novamente orientada pela preocupação do exibidor em atender às expectativas do público com relação à atualização temática das imagens, mesmo que o caráter recentíssimo de certos acontecimentos representados só permitisse o emprego de vistas fixas e nem sempre fotográficas, mas apenas ilustradas, como no caso da referida alegoria.

Ainda em 1906, foram exibidas vistas fixas nos espetáculos exclusivamente de projeções realizados por Candburg no Theatro Polytheama. A 
temporada, caracterizada pelo profissionalismo da organização e pelo sucesso, também contou com a promoção de um espetáculo de gala temático, comemorativo à Proclamação da República, que no entanto não foi divulgado com atenção especial pela imprensa. Sabe-se que nele foram projetadas vistas fixas, ao som do Hino Nacional, e que entre estas constavam "retratos dos srs. Rodrigues Alves, Afonso Penna e Nilo Peçanha", "recebidos com salvas de palmas" por um teatro "repleto de espectadores"111.

Uma nova temporada de exibição conjunta de vistas fixas e animadas ocorreu em 1907 e foi protagonizada pela empresa Baterlô \& C., ocupando o Theatro Polytheama para espetáculos exclusivamente de projeções. Sobre as vistas fixas e os seus conteúdos, porém, foram irrisórias as informações veiculadas pela imprensa. Em 1908, foram abertas em Porto Alegre cinco salas permanentes, especializadas em exibições cinematográficas, dando início ao processo de sedentarização da atividade. No entanto, nove exibidores itinerantes visitaram a cidade nesse mesmo ano, realizando temporadas exclusivamente de projeções em centros de diversões.

Dando mostra do crescente desinteresse pela exibição das vistas fixas e das projeções de lanterna mágica em geral como atrações de espetáculos públicos, apenas um exibidor as projetou durante a sua temporada: a Empresa Maciel \& Cia. Da mesma forma, a integração de tais imagens aos programas parece ter-se restringido a ocasiões especiais. Em seus espetáculos, realizados no Theatro São Pedro, predominaram as vistas animadas. E eles não teriam tido o sucesso que tiveram nem a cobertura da imprensa que tiveram se Maciel não tivesse se envolvido com os acontecimentos da cidade, promovendo a exibição de uma vista animada sobre o Carnaval local e de vistas fixas tematicamente associadas a ela. A iniciativa abarcou a comunidade relacionada com o desfile carnavalesco filmado, causando considerável repercussão na cidade.

A "vista do corso carnavalesco tirada no aparelho da Escola de Engenharia pelo fotógrafo Ferrari" 112 mostrava o "préstito brilhante que a Esmeralda apresentou nas ruas na tarde e noite de $2^{a}$ feira de Carnaval"113. Conforme esclareceu o Independente, o cinematógrafo pertencia à instituição de ensino, e a filmagem foi feita por um dos mais importantes fotógrafos locais, Jacintho Ferrari, cujo atelier, a Photografia Ferrari (Andradas, 254), completava 25 anos de existência em 1908. O seu envolvimento com a sociedade carnavalesca Esmeralda, porém, não se restringiu à produção do filme citado, sendo-lhe anterior e estendendo-se a outras manifestações e homenagens. Maciel participou da promoção apenas como exibidor da vista.

filme foi inicialmente apresentado em um espetáculo fechado, dedicado à Sociedade Esmeralda, seus convidados e associados, e a seguir num espetáculo de gala. $\bigcirc$ programa foi dividido em três partes, sendo a primeira dedicada à exibição da vista animada local, introduzida e sucedida por vistas fixas também locais. A segunda parte foi preenchida pela exibição de vistas animadas estrangeiras, e a terceira, pela reprise da parte inicial.

As vistas fixas da primeira parte eram ilustradas e fotográficas. Entre estas últimas constavam imagens de "diversos dos lindos e artísticos carros alegóricos"
111. Cf. A Federação, Porto Alegre, ano 23 , n. 265 , p. 2 , 16 nov. 1906.

112. Cf. A Federação, Porto Alegre, ano 25, n. 62, p. 2, 13 mar. 1908.

113. Cf. A Federação, Porto Alegre, ano 25 , n. 67, p. 2 , 19 mar. 1908. 
114. Ibidem. E, também, $A$ Federação, Porto Alegre, ano 25, n. 66, p. 2, 18 mar. 1908.

115. Cf. $O$ Independente, Porto Alegre, ano 8, n. 65, p. 2, 22 mar. 1908 .

116. Cf. A Reforma, Porto Alegre, ano 23 , n. 109 , p. 2 19 maio 1900; e, também, $n$. 105 , p. 2, 15 maio 1900.

117. Foram consultados três jornais diferentes a respeito: A Reforma, A Federação e o Correio do Povo, os únicos disponíveis nos acervos locais para o período. A primeira folha foi a mais informativa, enquanto a última praticamente ignorou a diversão, apesar da longa duração da temporada e do sucesso do Panorama. As informações, escassas e confusas, veiculadas na imprensa, somadas às dificuldades de esclarecimento de certos termos vocabulares empregados para descrever a atração, impedem o esclarecimento de sua natureza. do mesmo cortejo filmado, assim como da rainha da sociedade carnavalesca. Esta foi representada em duas imagens distintas, uma ilustração alegórica em cores e uma fotografia também colorida, onde aparecia vestindo o traje de gala usado no desfile e baile esmeraldinos. $O$ retrato do sr. Victor Barreto de Oliveira, presidente da associação, também foi exibido, seguindo-se a projeção de um longo texto em versos, saudando a rainha ${ }^{114}$. A cada vista apresentada, ouvia-se uma "prolongada salva de palmas" e uma "entusiástica ovação". Esse conjunto era finalizado por uma vista animada de uma "criança atirando um beijo"115.

De acordo com a larga e detalhada cobertura da imprensa, a função foi "uma verdadeira festa e assinalado sucesso". Mais do que um espetáculo de projeções, o evento tornou-se uma festa social da elite, e de celebração da sociedade carnavalesca, em que algumas das figuras que apareceram nas vistas constituíram-se também em atrativos vivos do espetáculo, ocupando os camarotes do teatro. A prática, envolvendo não somente os modos de mostrar, mas de ver e ser visto no ambiente espetacular público, expressou as implicações políticas e sociais dos usos das imagens, tanto em relação aos seus detentores quanto aos seus públicos. As vistas locais, animadas e fixas, foram produzidas e exibidas com 0 intuito de homenagear e distinguir a sociedade, o fotógrafo Jacintho Ferrari e o exibidor cinematográfico. Todos ganharam notoriedade e prestígio junto à comunidade local.

Os espetáculos públicos exclusivamente de projeção de vistas fixas, que foram raros na cidade no século XIX, cresceram numericamente entre 1896 e 1907, paralelamente ao incremento do comércio de projetores e das imagens do gênero existentes para uso doméstico. Os acervos de vistas exibidos nessas temporadas também foram incrementados formal e tematicamente, merecendo grande destaque - pela extensão, qualidade técnica e sucesso - a temporada do "Panorama Internacional". A denominação referia-se simultaneamente a um estabelecimento e a um tipo de diversão óptica que, em 1900, funcionou por mais de dois meses na rua dos Andradas, sob a direção de José Barrucci. Ali foram realizadas exibições diárias, noturnas, com duração de 30 minutos, em que o interessado podia apreciar " 50 belas vistas do mundo civilizado" por vez e "em tamanho natural"116. Tais características indicam que se tratava de um espetáculo de projeções, embora a carência de informações impeça a sua confirmação ${ }^{117}$. Por outro lado, não há dúvida de que as vistas exibidas, de temática turística, eram fixas e fotográficas, podendo inclusive ser estereoscópicas e, nesse caso, com efeitos de relevo e profundidade.

Era a primeira vez que um exibidor trazia à cidade conjuntos temáticos de vistas fotográficas de cidades, explorando de forma tão definida e qualificada o interesse pelo turismo. A sua coleção de placas contemplava localidades como Paris, Cannes, Nice, Berlim, Viena, Veneza, Roma, Gênova, Nápoles, Milão, Turim, Monte Carlo, Barcelona, Sevilha, Monserrat, Montevidéu e Buenos Aires, da Palestina, e de países como o Egito e o Canadá. Aí se apresentavam aspectos de suas ruas e avenidas, pontos turísticos tradicionais, edificações e monumentos, reproduzindo suas faces externas e interiores, além de panoramas das belezas naturais. A iniciativa levou a imprensa a literalizar claramente a percepção de 
que o "Panorama" oferecia ao público uma oportunidade inigualável de "viajar comodamente sentado pela Europa inteira"118. Em 1908, outro exibidor voltaria a oferecer aos porto-alegrenses espetáculos de projeções fundados na mesma temática, mas empregando apenas vistas animadas (Auto-Tours).

Além dessas vistas, Barrucci também apresentou conjuntos temáticos sobre acontecimentos, como a expedição do explorador Andréa ao Pólo Norte, as festas da abertura do canal em Kiel, o assassinato de Mr. Sadi Carnot e seus funerais, e a guerra ítalo-abissínia. A especificidade temática do acervo novamente aponta para a possibilidade da apresentação oral das vistas pelo exibidor, embora nada tenha sido informado a respeito. Na imprensa, a diversão foi frequentemente divulgada como "agradável, cômoda e variada", além de "instrutiva", sendo as vistas elogiadas por diferentes folhas, por sua nitidez e modernidade. Barrucci procurou impressionar o público local interessado no gênero já na primeira semana, alternando um variado repertório de imagens, que, com regularidade, renovou a cada dois dias. Possivelmente objetivava atrair uma mesma comunidade de espectadores a diferentes sessões, distintas pela programação. Ao divulgá-la, a Federação costumava dirigir-seaos "frequentadores" do "Panorama", evidenciando esta assiduidade.

As regulares repetições de determinados conjuntos de vistas a pedido de famílias demonstram a existência de uma relação de proximidade entre espectadores e exibidor, e a flexibilidade deste último na organização dos programas a partir das demandas do público. O sucesso ininterrupto do "Panorama" estimulou os jornalistas a expandirem seus comentários a detalhes arquitetônicos ou artísticos das edificações e monumentos representados nas vistas, assim como à informação de dados históricos sobre as cidades cujos pontos turísticos eram destacados. Tais iniciativas certamente contribuíam para o incremento da concorrência, considerando-se as expectativas criadas.

Em 1901, as vistas fixas foram apresentadas como atração exclusiva no Café Guarany, sob a denominação de Metempsycose. Divulgou-se que, sob esta excêntrica definição, ocultava-se uma "diversão muito em voga na Europa, que consiste em apresentações de vistas, cujos aspectos se transformam rapidamente à vista do espectador" 119 . Outra fonte acrescentaria que se tratava da "transformação, à vista do espectador, de figuras, que tomam, sucessivamente, novos aspectos, deleitando a vista" ${ }^{20}$. Tais descrições parecem indicar que o espetáculo consistia na projeção de vistas dissolventes de lanterna mágica, e que a excêntrica denominação tinha caráter meramente promocional, onde o emprego do atributo "novo" não correspondia necessariamente à qualidade da oferta. Após a estreia, a imprensa observou que a concorrência pública aos espetáculos havia sido "extraordinária", mas nada mais disse, provavelmente em função do sucesso que vinha fazendo no Theatro São Pedro o cinematógrafo de Henrique Sastre.

Em 1904, houve uma última ocasião em que foi realizado um espetáculo exclusivamente de projeção de vistas fixas, cujo destaque deve-se ao seu ineditismo no meio local, embora tivesse sido prática corrente na Europa. Trata-se de uma conferência, ilustrada com projeções de imagens fotográficas, realizada no Theatro São Pedro por dois viajantes estrangeiros, os irmãos Seljam. Em excursão pelo Brasil,
118. Cf. A Reforma, Porto Alegre, ano 23, n. 105 , p. 2 , 15 maio 1900

119. Cf. A Reforma, Porto Alegre, ano 34, n. 32, p. 2, 01 mar. 1901.

120. Cf. A Federação, Porto Alegre, ano 18 , n. 51 , p. 2 , 28 fev. 1901. 
121. Cf. O Independente, Porto Alegre, ano 4, n. 287, p. 2, 11 set. 1904 .

122. Cf. O Independente, Porto Alegre, ano 4, n. 290, p. 1-2, 22 set. 1904 .

123. Cf. A Federação, Porto Alegre, ano 24, n. 144, p. 2 , 20 jun. 1907.

124. Idem, p. 3.

125. Cf. A Federação, Porto Alegre, ano 24, n. 142 , p. 2 , 18 jun. 1907. após terem percorrido outros países da África e da América do Sul, os dois engenheiros chegavam agora a Porto Alegre, onde narrariam suas viagens com o auxílio de "várias projeções luminosas, dispondo para isso de aperfeiçoados aparelhos"121.

Na primeira parte do programa, os viajantes fizeram um relato multifacetado sobre a África Central (Abissínia, Somália, Etiópia), onde haviam passado três anos. Após um intervalo, teve início a segunda parte da conferência, dedicada ao Brasil e acompanhada pelas projeções de vistas e pela narração das viagens dos exploradores pelo interior do Rio de Janeiro até o Paraguai, passando por São Paulo, Paraná e Mato Grosso. No trajeto, os viajantes conheceram e fotografaram as Sete Quedas de Iguaçu e outras belezas naturais, queforam mostradas aos porto-alegrenses, proporcionando-thes novas informações, sobretudo visuais, sobre o seu próprio país ${ }^{122}$.

Surpreendentemente, em meados de 1907, nos espetáculos realizados no Theatro São Pedro pela Companhia Dramática Portuguesa, de Eduardo Vitorino, voltaram a ser exibidas projeções de vistas fixas de lanterna mágica, conforme a tradição do século XIX, como atrações de espetáculos de variedades. A diferença é que, desta vez, elas abriram os programas. Foi empregado Na ocasião, foi empregado um projetor francês Molteni, marca que distinguia projetores profissionais da mais alta qualidade técnica. Sua fonte de luz era elétrica e ele era capaz de projetar vistas dissolventes, o que indica que se tratasse de uma lanterna bi ou triunial.

Apesar de pertencer a uma tradição do século anterior e já defasada pelas projeções cinematográficas, o "Poliorama Molteni" foi promovido como um "verdadeiro sucesso dos teatros parisienses", como se fosse uma real novidade cuja incorporação pela companhia deveria valorizar o espetáculo como um todo. É possível, no entanto, que, nesse contexto em que o cinematógrafo reinava e se expandia, a companhia procurasse distinguir-se de suas congêneres e das práticas espetaculares correntes com a reapresentação nostálgica da lanterna mágica profissional.

O fato é que as projeções agradaram aos espectadores, "apresentando lindas vistas coloridas" 123 . No acervo da companhia, foram identificados conjuntos de placas ilustrando narrativas, cuja exibição certamente contava com acompanhamento oral:

o episódio burlesco em 12 quadros "Tribulações de uma porteira", verdadeira bexigada em 11 quadros "Um comilão em apuros", acontecimento cômico-romântico em 4 quadros "Uma conquista", a história ultra-cômica em 12 quadros "A casa dos feitiços"; a exibição do majestoso e comovente espetáculo em 24 quadros dissolventes "O Evangelho", continuação do sublime episódio da vida de Jesus Cristo ${ }^{124}$.

Cada quadro era uma placa de lanterna mágica, uma imagem, sendo que o último conjunto ( $O$ Evangelho), de temática religiosa, reunia ilustrações produzidas "a partir de desenhos de Habert, Brunetier, Sambeau e luzes"125. Os 
demais títulos correspondiam à linha de trabalho da companhia, especializada num repertório cômico.

Como se procurou demonstrar, as vistas ópticas, seja aquelas observadas individualmente, seja as projetadas para um grande público, proporcionaram diversão e informação, surpreendendo e maravilhando os espectadores com sua temática e beleza, cores, variedade, atualidade e efeitos diversos. Tais imagens participaram da ampliação dos horizontes culturais e da memória visual dos seus espectadores, num contexto de circulação ainda restrita de imagens e pessoas, permitindo uma apropriação visual do mundo e diminuindo, assim, as distâncias entre os homens e suas manifestações. Simultaneamente, elas abriram uma oportunidade de evasão e de sonho, de viagem imaginária, além daquelas proporcionadas pela literatura e pelo teatro, de apropriação mais restrita. Até então, nunca se havia descoberto tanto por intermédio do sentido da visão, nem este havia sido tão estimulado pelo setor do entretenimento.

Enquanto objetos e atrações espetaculares, motivaram práticas culturais, que, por sua vez, dinamizaram o setor do entretenimento local, produzindo e sustentando formas de sociabilidade. A observação das situações e associações que caracterizaram os usos dos dois gêneros de imagens - as vistas fixas e as animadas - como atrações distintas de um mesmo espetáculo, demonstra que a diversificação formal e estética das imagens ópticas proporcionou não somente uma multiplicação quantitativa e qualitativa de sua oferta cotidiana, mas também dos modos de mostrá-las e vê-las. Ao incrementá-los e atualizá-los, tais iniciativas contribuíram para a constituição de padrões visuais que orientariam a produção, circulação e apropriação das imagens naquele período e nos seguintes.

As vistas ópticas serviram como mediadoras de relações entre outras imagens, as práticas de sua exibição e as pessoas, produzindo ações e experiências sensíveis que contribuíram para a constituição de uma subjetividade estreitamente associada à visualidade como caráter de uma cultura, entendendo-se cultura como parte da vida social e "qualificação, pelo sentido, de todos os segmentos dessa mesma vida"126.

\section{REFERÊNCIAS}

\section{LIVROS, REVISTAS, CATÁLOGOS E PUBLICAÇÕES ELETRÔNICAS}

ALTMAN, Rick. Penser l'histoire du cinéma autrement. Un modèle de crise. Vingtième Siècle. Dossier Cinéma. Le temps de l'histoire, Paris, n. 46, p. 65-83, avril-juin, 1995.

. Quelques idées reçues sur le son du cinéma muet qu'on ne saurait plus tenir. In: PISANO, Giusy; POZNER, Valérie. (Org.). Le muet a la parole. Cinéma et performances à l'aube du XX siècle. Paris: AFRHC, 2005. p. 81-99.

ARAÚJO, Vicente de Paula. A bela época do cinema brasileiro. São Paulo: Perspectiva, 1976.

Salões, circos e cinemas de São Paulo. São Paulo: Perspectiva, 1981.
126. Cf. Ulpiano B. de Menezes (2003, p. 25). 
BERNARDET, Jean-Claude. Historiografia clássica do cinema brasileiro. São Paulo: Annablume, 1995.

BERNARDINI, Aldo. Les films Lumière en Italie (1896-1897). In: GUIBBERT, Pierre. (Org.). Les premiers ans du cinema français. Actes du Colloque International de L'Institut Jean Vigo, 5. Perpignan: Institut Jean Vigo, 1985. p. 67-70.

CERTEAU, Michel de. A invenção do cotidiano. Artes de fazer. Petrópolis: Vozes, 1994.

CHARNEY, Leo; SCHWARTZ, Vanessa (Org.). O cinema e a invenção da vida moderna. São Paulo: Cosac \& Naify, 2001.

CHARTIER, Roger. À beira da falésia. A história entre certezas e inquietudes. Porto Alegre: Editora da UFRGS, 2002. 1991.

O mundo como representação. Estudos Avançados, São Paulo, v. 11, n. 5, p. 173-191,

COSTA, Flavia Cesarino. O primeiro cinema. Espetáculo, narração, domesticação. São Paulo: Scritta, 1995.

DELTOUR-LEVIE, Claudine. Entre photo et cinéma. Bruxelas: Musées Royaux d'Art et d'Histoire, 2004.

FERREIRA, Athos Damasceno. Palco, Salão e Picadeiro em Porto Alegre no século XIX. Porto Alegre: Globo, 1956.

FILMOTECA ESPAÑOLA (Palacio de Perales, Madri). 50 años de la Filmoteca Española: El cine español en los años 50: catálogo. Madri: Filmoteca Española; Sociedad Estatal de Commemoraciones Culturales, 2003.

GASTAL, Suzana. Salas de cinema: cenários porto-alegrenses. Porto Alegre: Unidade Editorial, 1999.

GAUDREAULT, André; ALBERA, François. Apparition, disparition et escamotage du "bonimenteur" dans l'historiographie française du cinéma. In: PISANO, Giusy; POZNER, Valérie (Org.). Le muet a la parole. Cinéma et performances à l'aube du XX siècle. Paris: AFRHC, 2005. p. 167-199.

GUNNING, Tom. Cinema e História. In: XAVIER, Ismail (Org.). O Cinema no Século. Rio de Janeiro: Imago, 1996. p. 21-42.

LEENHARDT, Jacques. Teoria da comunicação e teoria da recepção. Anos 90, Porto Alegre, n. 8, p. 7-13, dez. 1997.

LEITE, Ary Bezerra. Fortaleza e a era do cinema, 1891-1931. Pesquisa Histórica, 1. Fortaleza: Secretaria da Cultura e Desporto do Estado do Ceará, 1995. Disponível em: <http://paginas.terra. com.br/arte/memoriadocinema/texto.html >.

LEVIE, Pierre. Montreurs et vues d'optiques. Bruxelas: Sofidoc, 2006.

LIMA, Solange Ferraz de. A expansão da cultura fotográfica: os processos fotomecânicos na economia de imagens do século XX. In: SIMPÓSIO NACIONAL DE HISTÓRIA CULTURAL, 3: Mundos da imagem, do texto ao visual, 2006, Florianópolis. Anais...Florianópolis: Anpuh-SC; Clicdata Multimídia, 2006.

MANNONI, Laurent. Le quatrième centenaire du cinéma. L'archéologie du cinéma e la naissance de l'industrie cinématographique. Théorème (Cinéma des premiers temps. Nouvelles contributions françaises), Paris, n. 4, p. 17-54, 1996. 
A grande arte da luz e da sombra. Arqueologia do cinema. São Paulo: Editora Senac São Paulo; Editora da Unesp, 2003.

Les appareils sonores du cinéma dit muet: petit panorama des collections françaises. In: PISANO, Giusy; POZNER, Valérie (Org.). Le muet a la parole. Cinéma et performances à l'aube du XX siècle. Paris: AFRHC, 2005. p. 101-134.

CAMPAGNONI, Donata Pesenti. (Org.). Lanterne magique et film peint, 400 ans de cinema: catálogo. Paris: La Cinémathèque Française; La Martinière, 2009.

MENESES, Ulpiano Toledo Bezerra de. Fontes visuais, cultura visual, história visual. Balanço provisório, propostas cautelares. Revista Brasileira de História, São Paulo, v. 23, n. 45, p. 11-36, 2003.

NABARRO, Max. Max Nabarro, explicador. Uma voz delante de la pantalla. Archivos de la Filmoteca, Valencia, n. 25-26, p. 144-154, feb.-jun. 1997.

PISANO, Giusy; POZNER, Valérie (Org.). Le muet a la parole. Cinéma et performances à l'aube du XX siècle. Paris: AFRHC, 2005.

PFEIL, Antonio Jesus. Cinematógrafo e o cinema dos pioneiros. In: BECKER, Tuio (Org.). Cinema no Rio Grande do Sul. Porto Alegre: Unidade Editorial, 1995. p. 17-29.

O cinematógrafo no Rio Grande do Sul no século XIX. Canoas: edição do autor, 1999.

RICE, Mark. Histoire de la Photographie. De 1839 à nos jours. Singapura: Taschen, 2005.

SCHWARCZ, Lilia Moritz; COSTA, Angela Marques da. Virando séculos. 1890-1914. No tempo das certezas. São Paulo: Companhia das Letras, 2000.

SILVA, Maria Cristina Miranda da. A presença dos aparelbos e dispositivos ópticos no Rio de Janeiro no século XIX. 2006. 252 f. Tese (Doutorado em Comunicação e Semiótica) - Faculdade de Comunicação, Pontifícia Universidade Católica de São Paulo, São Paulo, 2006.

SOUZA, José Inácio de Melo. O ano de 1902. In: MNEMOCINE: memória e imagem. 10 nov. 2005. Disponível em: <http://www.mnemocine.com.br>.

STEYER, Fabio Augusto. A. Cinema, Imprensa e Sociedade em Porto Alegre (1896-1930). Porto Alegre: EdiPUCRS, 2001.

TELESCA, Ana María. Salas de vistas ópticas. In: LEEDOR.COM: sitio de cultura. 22 oct. 2006. Disponível em: <http://www.leedor.com>

TRUSZ, Alice Dubina. Entre lanternas mágicas e cinematógrafos: as origens do espetáculo cinematográfico em Porto Alegre. 1861-1908. 2008. 421 f. Tese (Doutorado em História) Instituto de Filosofia e Ciências Humanas, Universidade Federal do Rio Grande do Sul, Porto Alegre, 2008.

JORNAIS

A Federação, Porto Alegre, 1897, 1898, 1899, 1900, 1901, 1903, 1904, 1905, 1906, 1907, 1908.

A Reforma, Porto Alegre, 1878, 1880, 1882,1883, 1887, 1899, 1900, 1901.

A Reforma. Órgão do Partido Liberal, Porto Alegre, 1878.

A República, Porto Alegre, 1896, 1898.

Annals of Museu Paulista. v. 18. n.1. Jan. - Jun. 2010. 
Correio do Povo, Porto Alegre, 1895, 1900, 1901, 1904, 1908.

Gazeta da Tarde, Porto Alegre, 1896.

Gazeta de Porto Alegre - Folha da Tarde, Porto Alegre, 1883.

Jornal do Comércio, Porto Alegre, 1901, 1908.

Mercantil. Folba da Tarde, Porto Alegre, 1894, 1895, 1896, 1897.

Mercantil. Órgão Federalista, Porto Alegre, 1896.

O Commercio, Porto Alegre, 1841.

O Independente, Porto Alegre, 1901, 1903, 1904, 1905, 1906, 1907, 1908.

O Mercantil, Porto Alegre, 1855, 1863, 1878, 1880, 1882, 1883, 1887, 1888.

O Século, Porto Alegre, 1887.

Jornal da Manhã, Porto Alegre, 1908.

SITES

<http://easyweb.easynet.co.uk/ s-herbert/peepshow.htm> (Museum of the Moving Image, Optical Room, Londres).

$<$ http://paginas.terra.com.br/arte/memoriadocinema/texto.html>.

$<$ http://users.telenet.be/thomasweynants/vue-optique.html\#oh> (Thomas Weynants, Early Visual Media, Bélgica)

<http://www.cinemateca.gov.br> (Cinemateca Brasileira).

$<$ http://www.geh.org $>$ (George Eastman House).

<http://www.kmkg-mrah.be> (Musées Royaux d'Art et d'Histoire, Musée du Cinquentenaire, Bruxelas).

$<$ http://www.leedor.com >.

<http://www.luikerwaal.com> (site especializado em lanternas mágicas, Holanda).

<http://www.mnemocine.com.br>.

<http://www.musee-mccord.qc.ca> (Musée McCord d'histoire canadienne, Montréal, Canadá).

<http://www.stereo-club.fr/grandes_dates.php.> (Stéréo-Club Français).

$<$ http://www.precinemahistory.net> (historiador do cinema canadense Paul Burns, The History of the Discovery of cinematography).

Artigo apresentado em 8/2009. Aprovado em 5/2010. 